49 | 2018

Human-environment relationships in Siberia and Northeast China. Knowledge, rituals, mobility and politics among the Tungus peoples, followed by Varia

\title{
An emic science of climate. Reindeer Evenki environmental knowledge and the notion of an "extreme process"
}

Une science émique du climat. Le savoir environnemental des Évenks et la notion de " processus extrême "

Alexandra Lavrillier and Semen Gabyshev

\section{(2) OpenEdition}

Journals

Electronic version

URL: https://journals.openedition.org/emscat/3280

DOI: $10.4000 /$ emscat.3280

ISSN: 2101-0013

Publisher

Centre d'Etudes Mongoles \& Sibériennes / École Pratique des Hautes Études

Electronic reference

Alexandra Lavrillier and Semen Gabyshev, "An emic science of climate. Reindeer Evenki environmental knowledge and the notion of an "extreme process"", Études mongoles et sibériennes, centrasiatiques et tibétaines [Online], 49 | 2018, Online since 20 December 2018, connection on 13 July 2021. URL: http:// journals.openedition.org/emscat/3280 ; DOI: https://doi.org/10.4000/emscat.3280

This text was automatically generated on 13 July 2021.

(c) Tous droits réservés 


\section{An emic science of climate. Reindeer Evenki environmental knowledge and the notion of an "extreme process"}

Une science émique du climat. Le savoir environnemental des Évenks et la notion de «processus extrême»

Alexandra Lavrillier and Semen Gabyshev

\section{EDITOR'S NOTE}

Map of the repartition of the Evenki in Russia and China

click here

Positions of the case studies in the present volume

click here

1. This paper is one of the results of a transdisciplinary research project bridging social anthropology, indigenous knowledge, and climatology on global changes in several Arctic societies, including the Evenki reindeer herders. After discussing the place of traditional environmental knowledge (TEK) in the framework of science, we present our innovative methodology, which offers some results from a co-production between social anthropology and indigenous knowledge. This paper argues that the Evenki possess an environmental knowledge similar to a science: this knowledge is vast, difficult to acquire, and indispensable not only for adaptation to their environment (considered extreme by the West), but also for understanding frequent and increasing contemporary climate and environmental changes. In the second part, the paper analyses emic perceptions of "extreme events": here we develop the notion of an "extreme process". 
Indeed, an extreme event is a broadly-used concept in studies of climate change in both the social and environmental sciences, notably in the Arctic. Some anthropological studies claim that Arctic indigenous peoples do not possess a notion of "extreme" or "extreme event" because they are used to constantly adapting to their harsh environment. But is this the case for the Evenki, especially given the abrupt rise of changes observed in Siberia from 2005? Based on long-term field-studies and coproduction in the vernacular language, we found that this indigenous people has an emic and detailed understanding of "norms" (e.g. their harsh environment in its normal state, including variations), diverse types of "anomalies" (Evk. dikte) they can deal with, and various "degrees of extreme event" that they relate to the extent of their adaptive capacities. Their scale moves gradually between two points, from a set of rare conditions with significant consequences to which Evenki society strives to adapt ("out of sync", Evk. manak) to the most complex "extreme process", designating conditions to which society can no longer adapt (Evk. davdavse). This proves the existence of a complex indigenous cognitive system regarding the interelations between humans, the environment, and climate; this system contains also notions of social limitations (see below).

\section{To be or not to be a science}

3 First of all, we use the word "science" to denote a system of knowledge ${ }^{1}$. Our starting postulate was to consider traditional ecological knowledge as a science that can collaborate, complement, enrich, and be merged with the social and environmental sciences.

There are numerous definitions of TEK, beginning with the one provided by Berkes: "TEK is defined as a cumulative body of knowledge, practices and beliefs about the dynamic relationship of living beings with one another, and with their environment, which has evolved by adaptive processes, and has been handed down from generation to generation" (Berkes 1999, p. 8).

5 Huntington defines it as "a system of experiential knowledge gained by continual observation and transmitted among members of a community. It is set in a framework that encompasses both ecology and the interactions of humans and their environment on physical and spiritual planes" (Huntington 1998, Burgess 1999).

6 "Experiential knowledge", "practical knowledge", and "knowledge in practice" are expressions often used as synonyms for TEK (Helander-Renwall 2005, p. 4, et passim), as is "way of life" (as many publications stress, like Nadasdy 1999, p. 4, Berkes 1999, p. 8).

7 Thus, TEK is often seen as being exclusively "practical", supremely concrete, collectively inherited, and very different from Western sciences in terms of the production of knowledge. For instance, Nadasdy writes, "in contrast to TEK, which is assumed to be qualitative, intuitive, holistic, and oral, science is seen as quantitative, analytical, reductionist, and literate" (Nadasdy 1999, p. 2).

According to our research, Evenki TEK is not just a block of information and practices transmitted from generation to generation. Nor is it intuitive: it is as conceptual (that is to say, it contains many concepts), theoretical, and analytical as a science ${ }^{2}$ (Lavrillier \& Gabyshev 2017). 
9 The recognition of TEK as a science also implies epistemological and ethical issues at the scientific and political international levels, as stressed, for instance, by the recent definition of TEK improved and agreed upon by the different Arctic peoples involved in the Indigenous Secretariat of the Arctic Council. This states that "Traditional Knowledge is a systematic way of thinking and knowing that is elaborated and applied to phenomena across biological, physical, cultural and linguistic systems. Traditional Knowledge is owned by the holders of that knowledge, often collectively, and is uniquely expressed and transmitted through indigenous languages. It is a body of knowledge generated through cultural practices, lived experiences including extensive and multigenerational observations, lessons and skills. It has been developed and verified over millennia and is still developing in a living process, including knowledge acquired today and in the future, and it is passed on from generation to generation". Then it identifies 13 principles that must be attached to TEK, including its political significance, the notion of authorship, and rules of collaboration with sciences (Retter 2015).

10 While providing a definition of an "indigenous knowledge system" may be superfluous for specialists in ethno-biology and ethno-science and most anthropologists, we will nonetheless provide one here: "The system of thought analogous to scientific understanding within traditional cultures. The notion implies that such knowledge is indeed systematic in a similar way to modern science" (Barnard \& Spencer 2005, p. 911).

11 The value of TEK "has been widely recognized in fields such as agroforestry, traditional medicine, biodiversity conservation, customary resource management, applied anthropology, impact assessment and natural disaster preparedness and response" (Nakashima et al. 2012, p. 27).

Despite all of this, the unequal hierarchical positions of the environmental sciences and TEK remain one of the hindrances to indigenous knowledge taking a more prominent position in climate change research and policy. Indeed, worldwide indigenous leaders, including some Arctic ones like the Inuit S. Watt-Cloutier, are still struggling to receive general and official recognition of their climate change observations and knowledge as being of scientific value. Thus, TEK is still not officially recognised as a science despite several dozen years of efforts from international organisations (UNESCO, UNEP, special task forces within UNFCCC, IPCC, and IPBES 3 ): it has not been systematically integrated into environmental change research and has not really been voiced in climate negotiations ${ }^{4}$.

The fact that TEK is not officially recognised as a science could perhaps be linked to some specificities of the West, where the current sciences were institutionalised. For instance, Said stated that Western researchers have reproduced stereotypes about the Western world as the cradle of progress, rationality, and science, while stereotypes of irrationality and myth are attached to the rest of the world (Said [1978] 2006). The perception of TEK as irrational is also argued by Obeyesekere (Obeyesekere 1992). With regards to the relationship between social organisation and science, we could refer to Bourdieu, who describes academic knowledge as a "political resource" to keep away from the masses that allots a "symbolic power" and should be kept away from the masses (Bourdieu 1984). These topics are further developed by anthropologists of science like Nader and Scott (Nader 1996), who examine Western science in the context of and in contrast to traditional knowledge by considering power dimensions, the 
"ethnocentricity" or the "cultural ascendants of science". They also contradict "the omnipresent image of Western science as 'pure' and 'independent from politics', like for instance in the chapter 'Science for the West, Myth for the Rest". The authors of the present paper think that this could also be because the transmission and validation of the acquisition of TEK (through orality and experimentation) is, according to the Western worldview, too different from or not valid in comparison to the transmission and validation of the sciences (in writing and through the institutionalised attribution of diplomas and hierarchised academic positions). In addition, as the authors could note for Evenki TEK, there is a lack of in-depth documentation for many TEK systems. Such documentation could help calibrate TEK with science, an idea shared by the IPCC (IPCC 2014b, p. 844). The authors will develop these issues in another paper.

Instead of being truly recognised as scientific input, TEK occupies a different place in international climate and environmental assessments and negotiations. It is described in the Assessment Reports (AR4, AR5) of the IPCC 2007 and 2010 as "an invaluable basis for developing adaptation and natural resource management strategies in response to environmental and other forms of change": thus, it is treated as a separate topic within the chapter on human security (Nakashima et al. 2012). Similarly, the international Convention on Biological Diversity (CBD), which entered into force in 1993, only demands that the signatory countries respect and maintain TEK and indigenous practices. A turning point came in 2015 with article 7 of the Paris Agreement, with the COP 21 of the IPCC stating that "adaptation action should be [...] guided [...] by the best available science and, as appropriate, traditional knowledge systems" (UNFCCC 2015, p. 11). However, this has largely not been implemented in practice and seems to have been ignored by the powerful states.

According to the first author's analysis of the IPCC's last report (IPCC 2014a, b, c), TEK is very rarely mentioned in both synthetic and mitigation reports; if it is, it is described as being embedded in belief systems, often damaged by climate change, but sometimes still able to reduce uncertainty for human adaptation (IPCC 2014a, c). A section of 17 lines devoted to TEK, quoting Nakashima et al. 2012, says that it "is often marginalised in decision making and unable to participate adequately in local [...] and international climate change mechanisms". TEK appears much more frequently in the adaptation and vulnerability report (IPCC 2014b). TEK is recognised by the vast majority as a "'non-scientific' source of information and observations that has a great value for indigenous peoples adaptation" (including some climate services) that must be taken into account in climate policies.

Thanks to scientists who have already developed collaborations between TEK and sciences, such as Crate (Crate 2008), Forbes (Forbes et al. 2009), Ford (Ford et al. 2006), Huntington (Huntington et al. 2004), etc., the report very occasionally states that TEK can enrich research on the impact of climate change and improve indigenous adaptive strategies. It is said to be a "valued knowledge system that can, together with or independently of natural sciences, produce useful knowledge for climate change detection and adaptation" (IPCC 2014b, p. 1001). Nevertheless, TEK-science collaboration is seen as challenging for both cultural and epistemological reasons (ibid., p. 766) and because it is said to be valuable only locally. Furthermore, TEK is now often presented as less reliable because of changing environmental conditions or new extreme events (ibid., p. 766, Ford et al. 2006) 
Successful stories of collaboration or co-production between TEK and the sciences, including calibration of respective scales, are mentioned extremely seldom. We found only two mentions that recognise TEK as motivating scientists to study new issues relating to climate change impact, despite the fact that TEK has inspired numerous academic research. We did not find any discussions of the notion that TEK can provide some strictly scientific input or findings, including on a theoretical level: nor are there any suggestions that it should be recognised as a science.

In scientific research, interest in TEK experienced an impressive surge during the 1980s, with numerous conferences, seminars, and workshops dedicated to it (Berkes 1999, Nadasdy 1999). Around 15 years later, it reached some parts of the Arctic (Canada, Alaska, and Greenland). By the end of the 1990s, "an emphasis on local and traditional knowledge and participatory research has helped create a paradigm shift: scientific studies can no longer take place in the Canadian Arctic without some communication and consultation with a local community" (Gearheard \& Shirley 2007, p.63). In contrast, this research theme and approach were relatively novel in Far Eastern Siberia (except for Crate 2008, Bogoslovskaia et al. 2008 and later publications); equally, collaborative research with indigenous peoples is still not the scientific approach generally chosen in Russia (see below).

\section{Raising new transdisciplinary and participative methods and research}

Our project took place in Southern Yakutia (Aldan) and the Northern Amur region. 18,232 Evenki live in Yakutia and 1,501 in the Amur region: around 70\% live in remote villages 5 . Approximately only $30 \%$ of the entire Russian Evenki population in Russia still lead continuous nomadic lifestyles. Some members of the intelligentsia live in towns. For the majority of these populations, however, the main source of subsistence, as well as other resources, is the natural environment (game and fur hunting, reindeer herding, fishing, and gathering berries and mushrooms). In the regions with which the paper is concerned, a higher percentage of nomads are attached to villages where the Evenki language has been well conserved ${ }^{6}$. Their native language is not only a mean of communication, but also a vehicle of knowledge (including TEK).

present study comes from BRISK's ${ }^{7}$ Evenki Community-Based Transdisciplinary Observatories (Evenki C-B observatory). The study was conceived and carried out by A. Lavrillier (an anthropologist), S. Gabyshev (a Evenki reindeer herder and hunter), and L. Egorova (a Evenki weather forecaster) from January 2013. The project's coproductions were also completed by the heavily involved herder-hunters Vasilii Gabyshev, Albert Kolesov, Oleg Iakovlev, and the herders who gave interviews and more occasional information (e.g. around 20 families $^{8}$ ).

So, in addition to a previous monodisciplinary anthropological study, the present study is based on data for the period from winter 2011 to winter 2018: this information was gathered in accordance with socio-anthropological and transdisciplinary methods (TEK, weather forecasting, and anthropology).

This idea for such an approach came to the first author in 2011 after five years of studying perceptions of climate change and adaptive practices among the Evenki (Yakutia and the Amur region) and Even (Yakutia and Kamchatka) reindeer herders 
and hunters via the classical methodologies of social anthropology (Lavrillier 2011b, 2013). While it was only through these methods (see below) that it was possible to analyse the socio-economic impact of climate change on society and adaptation, they gave a superficial understanding of the knowledge the Evenki had of this subject. Indeed, while the anthropologist was the recipient of a significant number of observations regarding the climatic and biophysical states of the environment, she did not really understand them (despite her knowledge of Evenki language and society) and did not know what to do with them: they were too distant from the themes of classical anthropology.

Starting from the point that herders and hunters are frontline witnesses of profound global change in their environment, our project was to organise a community-based observatory with the herders that would attempt to merge the methods of nomads, social anthropologists, and environmental scientists. Thus, the second author quickly became the most involved reindeer herder thanks to his taste for the intellectual exercise of transdisciplinary observations and analysis and his capacity for innovation. Since she possesses the same interests and skills (and also because she combines both types of knowledge - some TEK from her reindeer-herding family and scientific knowledge from her background as a weather forecaster), L. Egorova became the second main indigenous developer of this observatory.

Our methodology consisted of daily observations performed by the nomads, collective documentation of TEK by nomads and the anthropologist, anthropological fieldwork twice a year for collective observation and documentation, and an anthropological study of the perception of changes, the ways they are faced, adaptive strategies, and potential vulnerabilities. In addition, Gabyshev, as the main observer and co-designer of the project, went to Paris several times to work with climatologists, geographers, anthropologists, and Sami reindeer herders in meetings, collective analysis of materials, the transcription and translation of numerous interviews, and co-writing sessions.

More precisely, from 2013 to 2018, thanks to the co-production methods (daily observations and collective expeditions) that we developed with herders in the Evenki C-B observatory, we co-produced the following data and analyses:

- Transdisciplinary meteorological data monitoring: 1) Western meteorological measurements with mobile thermometers and fixed thermo-buttons of temperature, humidity, precipitation (including snow cover measurements), and wind variations, which were made daily by the nomads; 2) measurements made according to the traditional nomadic meteorological system (monitoring the emic physics of snow and ice and the evolution and behaviours of flora, fauna, and domestic reindeer for 56 months). This monitoring is still ongoing within our new project, BRISK's OBS ENV.

- Co-analysis of abnormal winters and summers (including events considered "extreme" by the nomads). The analysis was conducted with reference to both TEK and social anthropology. It demonstrated frequent anomalies in the evolution of the snow and ice cover and significant variations over different topographies. In addition, these anomalies seem to cause considerable changes in the vegetal cover. A very small section of this data is used in this paper; another section was used in a collective analysis by the climatologists M. Rojo and C.Claud and the authors. An important section is published in our book (Lavrillier et al. 2014, Lavrillier \& Gabyshev 2017, pp. 243-383, 370-450). 
- Evenki TEK documentation: the authors (with other herders) developed TEK co-productions about environmental changes and land use by mapping and measuring the many nomadic roads, camps, and sacred places of this huge area. Some of these maps were used in and merged with remote sensing analysis by S.Gadal, M.Dal Mollin, S. Gabyshev, and A. Lavrillier.

- The socio-economic effects of these changes were studied in detail (sometimes collectively with herders). Nomads adapt by modifying some herding/hunting practices. These adaptive practices are today threatened by the local development of extractive industries, as we will see in this paper.

One of the greatest difficulties was to adapt methods of measurement and other requirements from the environmental scientists to the nomadic world and to create a real dialogue between herders and environmental scientists: this was for both epistemological and hierarchical reasons (see above and below). In this, the role of social anthropologist was central, a point also noted by Crate in her own transdisciplinary research (Crate \& Fedorov 2013, p. 339).

\section{Social anthropology versus knowledge co-production}

Thus, we have tested two methods for studying climate change among reindeer herders. The first was classical social anthropology, with participant observation, semistructured interviews, and a research perspective oriented on Evenki society. One of the first results of this approach shows that climate change is faced and perceived together with other global changes (ecological, geopolitical, economical, and juridical) that threaten reindeer herding. In this framework of abrupt combined changes, the unpredictability of the weather and climate is a source of anxiety and requires constant adaptations: these are allowed by TEK.

The second method we tested offers a completely different perspective by studying and documenting climate and environmental changes with Evenki herders as "coresearchers". The herder-hunters permanently involved in the scientific process had the status of "co-researcher". As with projects involving participatory research (also called "citizen science", where non-scientists take part in scientific observation), this caused an important change in the research process, since indigenous peoples are no longer considered to be the "observed". We refer here to the "great divide" in anthropology, the asymmetrical distinction between "us" (e.g. Westerners, the "observers") and "them" (e.g. indigenous peoples, the "observed"), a distinction inherited from the colonial period that influenced the social sciences over the course of several decades (Fabian [1983] 2014, Lenclud 1996, among others). Equally, one might mention the propensity identified in the traditions of the Western sciences to maintain total control over the subject of study (Latour [1991] 1993). In the Evenki part of the project, herder-hunters are "co-observers" of the natural environment and its inhabitants (humans and animals). The status of "co-researchers" was accepted by our institutions (OVSQ, UVSQ, ANR, UNESCO, French Embassy's Office for Scientific collaboration, etc. ${ }^{10}$ ). S. Gabyshev was officially recognised as a CEARC laboratory fellow in 2013, took part in laboratory meetings and research workshops, and offered seminars for UVSQ students. In 2018, he was nominated for the French academic award Chevalier dans l'Ordre national des Palmes Académiques for his active participation in research. 

transdisciplinary project, their participation in co-research and daily observations have deepened their knowledge and their ability to forecast changes in the weather and the environment. Firstly, they were agreeably surprised by the interest from environmental scientists in their TEK and appreciated the exchanges of knowledge during workshops, seminars, conferences, and co-writing sessions. It was extremely important for them to see their involvement and input officially recognised by awarding them the status of co-researcher and placing their names in the copyright labels for conferences, papers, and books. Sometimes they were surprised that scientists have no knowledge of phenomenon obvious to nomads and how scientists can sometimes write about subjects of which they know little. It was also very important for the herders to finally have their concerns about the worrisome changes in their environment heard.

\section{An emic science of climate}

Very rapidly, it became clear that it was impossible to go further in our transdisciplinary observation without studying in greater depth Evenki TEK as a system. During the installation of the C-B observatory, the first author came to 
understand that Evenki TEK is a vast and sophisticated system of knowledge attached to complex processes of cognition. It became apparent that this knowledge is not only a set of practical "knowledge packs", but also a real theoretical system, containing a lot of "know how", hypothesising, and predictions. Indeed, some cognitive operations can be compared to "modelling" (Lavrillier \& Gabyshev 2017, pp. 438-449, 456-457). This knowledge, just like the Western sciences, is not only based on the transmission of knowledge between generations: it also questions existing knowledge, performs experiments, produces new knowledge, takes measurements, forms theoretical constructions, and uses specialised terminologies shared by only part of the community (ibid.) (see the definition of science at the beginning of the paper). So, like in science, the notion of the authorship of innovation exists in Evenki TEK. In addition, it is not only a science of weather, but also of climate, since nomads produce hypotheses several years in advance ${ }^{12}$.

However, in contrast with the Western sciences, emic environmental knowledge (or science) is highly systemic. It is not only interested in one single element: rather, it is focused on the many interactions between numerous elements in the natural environment (see further).

Thus, it is very difficult to access this knowledge. First, it is encapsulated in the Evenki language and is often very difficult or impossible to translate. Second, this knowledge is so vast that not every nomad possesses it in its entirety: villagers, townspeople, and even linguistic specialists remain ignorant of it. Third, herders and hunters are not very talkative. Fourth, the memory of this knowledge has some temporality; for instance, the Evenki can easily remember the terms for the state of the natural elements in a given season, but sometimes temporarily forget the terms used during other seasons. Fifth, TEK is often sporadically delivered piece by piece by the nomads: initially, they often provide a very laconic explanation from which the Westerner understands little or nothing. It takes hours or even days of further explanation, misunderstanding, clarification, and diagrams to create a co-production accessible to Westerners. To obtain knowledge, it is often necessary to wait for nomads to meet some specific kinds of snow, ice, and species or to catch a new word or phrase from their spontaneous daily discussions.

In order to increase the speed with which the knowledge was being delivered, the first author discovered a new method. When alone in the forest, she took pictures of everything; when back in the tent during the evening, she showed the nomads her pictures and asked for explanations. We then developed the method of imposing colour drawings and diagrams onto the pictures in order to explain and express indigenous knowledge. With time, the herder-observers themselves started to propose pictures, drawings, diagrams, and other pieces of knowledge. Among the nomads, some individuals got caught up in the game of scientific investigation and proposed their own research ideas, concepts, and hypotheses: they also enthusiastically engaged in cowriting. Thanks to these methods, we were able to identify several TEK typologies (see below).

It is impossible to expose all this knowledge, demonstrate the full complexity of this emic climate science, or show all our findings in this paper: indeed, we could not fit it into the almost 500 pages of our book (Lavrillier \& Gabyshev 2017). Nonetheless, we will try to briefly summarise some specificities by focusing on climate and emphasising how 
this knowledge allows the Evenki to manage their environment, deal with variations, and face anomalies.

After one year of intensive research and observations with herders, it became clear that Evenki emic science is based on what we call "typologies". Thus, such a typology is a set of term-concepts (e.g. types) designating the specific state of an element or different elements of one emic realm. Herders articulate it in order to analyse norms and anomalies of past or present processes or in the production of predictions and hypotheses for the future (see below). The cognitive operations that come with these analyses are crucial tools for successful adaptive strategies. For instance, mastery of landscape and snow/ice typologies (and of the interactions between snow types and landscape types) allows a herder to adapt by predicting where he/she will find a good snow cover. There are typologies of topography, vegetal cover and fauna, and what we call "the human-made landscape". There are also some concepts that reveal specific interactions between the elements of the environment and their human and animal inhabitants, like arbun solgu/ arbun edighu. This concept allows people to determine (according to a position in reference to the main winds, the circulation of sun, and river flow) the peculiarities of a place in terms of snow and vegetal covers, pastures, animal presence, the rapidity with which the snow melts, and its quality as a nomadic camp (ibid., pp. 116-118).

The emic science of climate includes several typologies. There is a complex typology of warm and cold air and deep knowledge about air circulation (ibid., pp. 217-242). The latter is thought to be determined by, among other things, the specificities of topography, vegetal cover, and sky-ground interactions (Fig. 1). According to the Evenki, this is one of the factors that establishes the microclimates they use as a part of the logic of organising nomadic travel (Lavrillier 2005-2006). This typology also has an emic system of temperature measurements.

Figure 1. One of ten diagrams explaining the emic term-concept idia (one of the types of cold air)

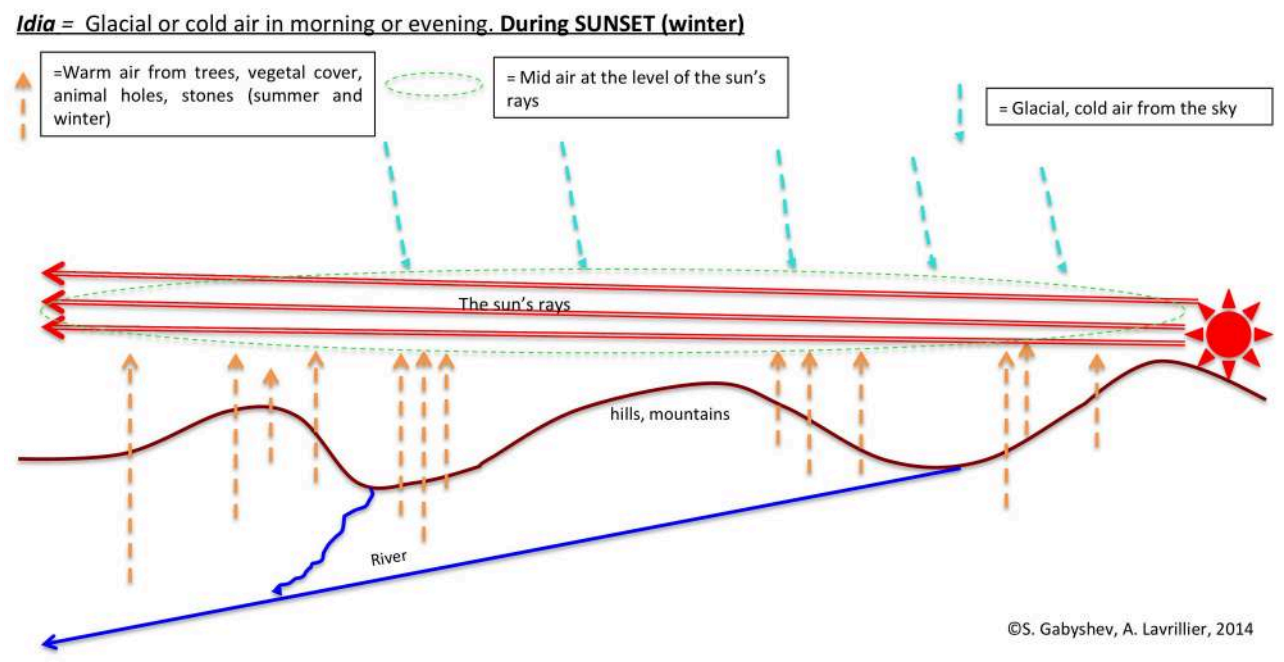

Stage 1/3: Before the appearance of idia (sunset) At the beginning of the sunset, the mid air is warmed by the sun and acts as a barrier which prevents cold air from descending from the sky. It also stops the warm air (from the ground) from rising into the sky. The presence of the mid air can be seen when rising fog hovers at this point in the air and rises no further.

(c) S. Gabyshev and L. Lavrillier, 2014 (published in Lavrillier \& Gabyshev 2017, p. 233) 
In addition, there is a typology of wind that includes some seasonal winds and a compass rose that identifies regular changes in the wind and the consequences for precipitation and the weather. For instance, first, a wind from the south (Evk. namuscheren) brings warmth; second, a wind from the east brings clouds and light wind; third, a northern wind brings snow. Then the wind changes and comes from the west, bringing clear weather; and so on. In the summer, with the exception of namuscheren, which brings warmth and rain, the same winds bring other events: the wind from the north brings enduring rain, while the wind from the west brings, most of the time, thunder clouds (Fig. 2).

Figure 2. Regular changes of wind types and their consequences

Regular changes in the winds and its consequences for precipitation and the weather - Indigenous hypothesis - Winter and snowy spring

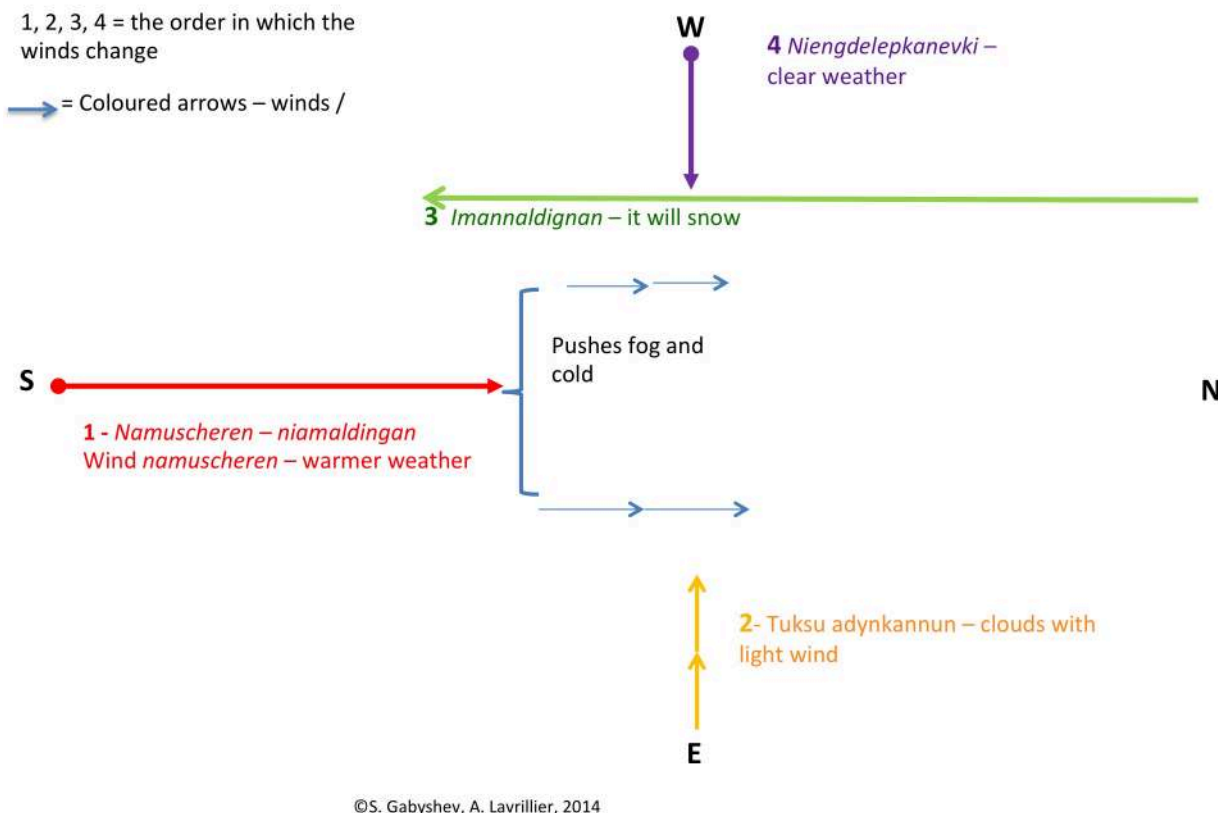

(c) S. Gabyshev and L. Lavrillier, 2014 (published in Lavrillier \& Gabyshev 2017, p. 224)

41 There are also typologies of clouds and precipitations that consist of around 20 elements, some of which are supposed to have relationships with the life cycle of insects.

42 Finally, there is an extremely rich and complex typology of snow and ice. We identified eight ice types and 25 snow types, with an understanding of the norm for chronological appearance (admitting variation in the date of arrival). We also documented the complex emic physics of snow and ice (based on this typology), which conceptualises very precisely the required conditions for each physical transformation from one snow type to another (temperature, humidity, wind, etc.) (Fig. 3). It also conceptualises the influence of snow and ice types on vegetal cover and, in some cases, vice versa (ibid., pp. 434-443). Evenki nomads regularly analyse the surrounding snow covers and have their own methodologies of analysis and measurement (ibid., pp. 279-345, 389, 398, 401-433'13). 
Figure 3. The Evenki emic typologies which allow them to analyse norms and anomalies in the snow cover.

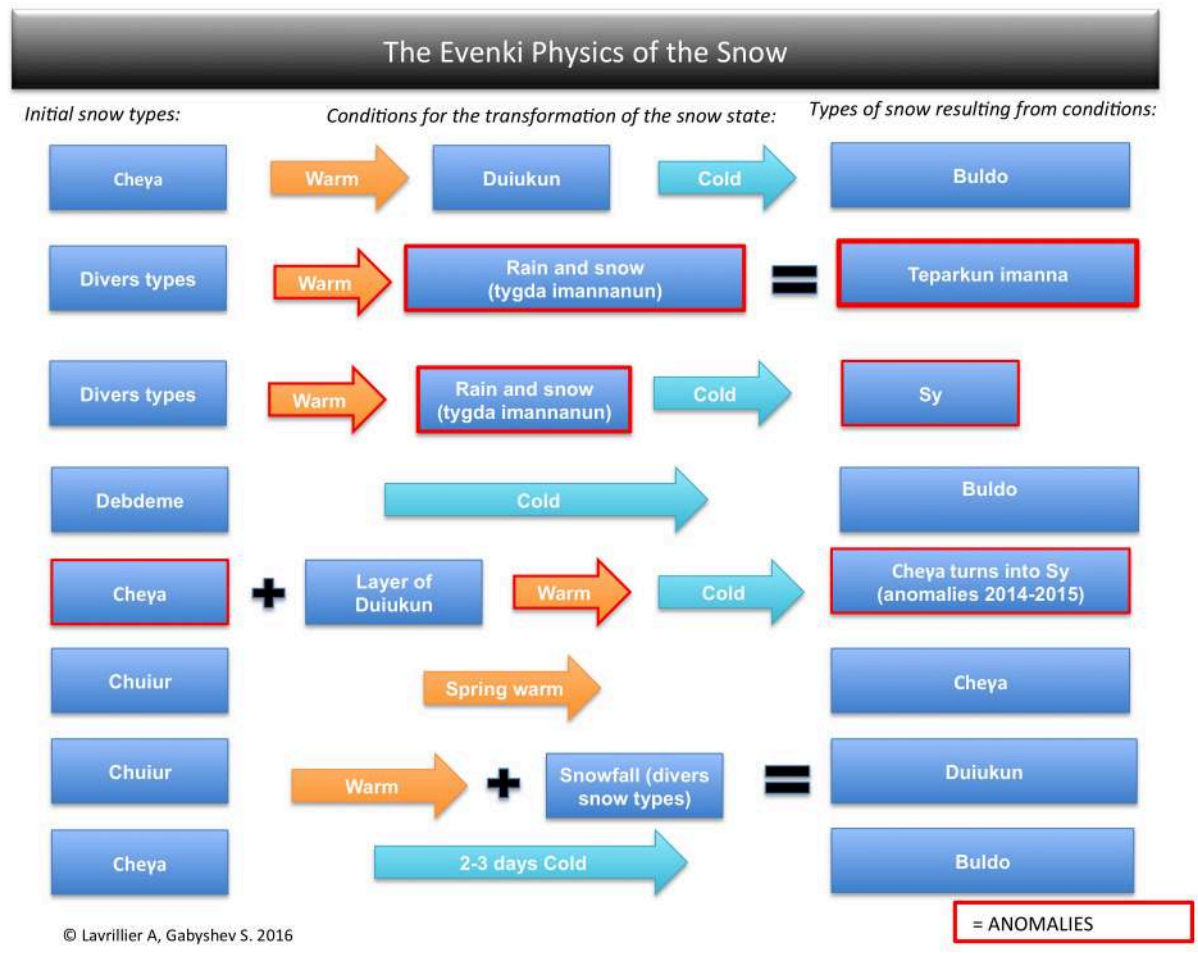

This is a table demonstrating Evenki snow physics

(c) L. Lavrillier and S. Gabyshev 2016 (published inLavrillier \& Gabyshev 2017, p. 283) detailed inter-seasonal steps: they also have a chronological chain that admits variability in the arrival of expected seasonal or inter-seasonal events (ibid., pp. 164-175).

ccording to our study of the daily observations, the subdivision of time into months seems to be much less significant in the traditional Evenki calendar than its subdivision into large seasons and inter-seasonal periods. The conceptualisation of these periods, highlighted by a specific terminology, engages all the typologies quoted above, thus constituting a complex cognitive system. For instance, the spring without snow (approximately between May and mid-June depending on the micro-climates) is 
divided into 4 sub-seasons determined by the behaviours of young leaves, mosquitoes, flowers, insects, and fish (ibid., pp. 161-174).

So, we worked in parallel on two paths of study: one centred on a systematic study of the TEK system and the other on monitoring changes. We simultaneously examined normal processes and anomalies (see examples below). We could understand Evenki anomalies and norms only thanks to knowledge about emic "typologies".

Evenki climate science defines norms that admit variability. However, this system sometimes no longer works: events occur beyond the admissible limits of variability and beyond known anomalies. In other words, TEK sometimes fails to analyse or understand weather or climate "over-variability" (see below).

According to our analysis, Evenki herders make the following differentiation. First, there are emic norms that include a set of variations (see below). Second, there are known anomalies (already observed from year to year, information of which is transmitted from generation to generation). Third, there are unprecedented anomalies (never observed before according to collective memory) that cause great anxiety (Fig. 4). We noted several of these phenomenon between 2011-2017, including some emic "extreme events". In our analysis, we noted that both kinds of "anomalies" do not necessarily mean an "extreme event" or catastrophe for the nomads if they do not endanger life or the economy (see below). However, there is a difference between "known anomalies" and "unprecedented anomalies", since the latter create anxiety or, occasionally, panic among people, even if the event does not threaten them. Indeed, they face an unknown reaction from the natural environment that they cannot understand. This angst is expressed in exclamations in Evenki like "nature is broken" (Bugha ukchapcha) (ibid., pp. 253-254) (see below).

Figure 4. Norms and types of anomalies according to Evenki TEK

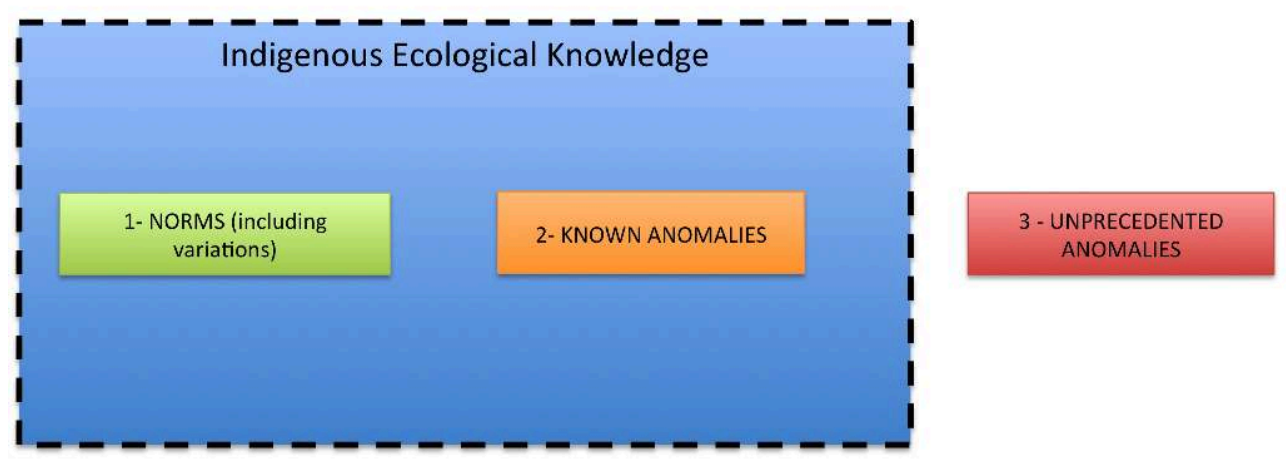

(ㄱ) A. Lavrillier, 2016

(c) A. Lavrillier 2016 (published in Lavrillier \& Gabyshev 2017, p. 253)

49 It is largely recognised by international Arctic research that climate change heavily affects circumpolar Arctic communities and is jeopardising their traditional economic activities (IPCC 2014b, pp. 718, 765, 1014, et passim). A few researchers argue, for various reasons, that climate change is not extreme for Arctic indigenous peoples. M. Therrien, for instance, states that climate change "is not extreme for the Inuit" because they have always lived in what the West describes as an extreme and changing environment; similarly, Nuttal describes Arctic peoples as being prepared for change (Therrien 2007, Nuttal 2009, p. 298). Golovnev shows how Nenets reindeer herders were able to recover 
(twice) from the loss of several thousand reindeer after the 2013-2014 ice-covered tundra episode prevented the reindeer from accessing pastures and the 2016 anthrax outbreak (Golovnev 2017, pp. 41-47). However, as we will see, situations can vary greatly in the Arctic; equally, climate change has reached a crescendo in Siberia from 2005 , as observed by both nomads and climatology. While we noted high adaptability among the Evenki, they also expressed the existence of various "extreme events" and that their adaptation capacity has reached its limit in the course of their encounter with "extreme processes" (see below).

Before analysing the Evenki emic notion of an "extreme event", let us briefly analyse the understandings attributed to their vernacular words for "weather" and "climate" and to the Russian for "climate".

51 When Evenki want to ask about the weather, they use the vernacular word bugha, such as in sentences meaning "What is the weather?" or "How has the weather changed?" (Ekudy bugha?, On bugha ocha?). As explained below, the word bugha is also used for designating climate when talking about climate change.

Bugha has multiple meanings in the Evenki language and the dialects of the coresearchers: it designates, depending on the context, the entirety of the biophysical natural environment, the spirits inhabiting it, the main spiritual entity in control of the natural environment, the sky, and native land (Cincius 1975). The use of this unique word for "weather", "climate", "sky", and the "entire biophysical environment" confirms the holistic and systemic perception of the nomads.

In addition to this, Evenki have a specific understanding of the Russian term klimat (basically, the equivalent of the English "climate"). Their understanding includes many elements. For instance, nomads and villagers see a relationship between climate and industrial development:

The climate entirely changed. There is probably now a lot of radiation because humans "opened" the earth everywhere to extract titanium, gold, coal, and diamonds; they also opened a new spaceport and so on. Radiation came out of the ground. This is why our reindeer became fragile or ill ${ }^{14}$.

We can see here that nothing is said about the weather when explaining climate change. This Evenki understanding of the word klimat is so holistic and systemic that it includes the entire natural environment and human activities (indigenous and nonnative, local and global). It thereby focuses on the interplay between the elements of the environment (including climate) and human factors.

Nevertheless, as we have seen above, this holistic perception does not contradict the existence of an emic science clearly centred on what Western sciences call "weather" and "climate".

We will see now that these understandings have a common logic with the Evenki notion of an "extreme event ${ }^{15}$ ".

\section{From "extreme events" to the notion of an "extreme process"}

57 To understand the Evenki concept of an "extreme event", it is important to briefly introduce the socio-cultural, economic, and political context. This is because the Evenki 
perceive some of these events to be the accumulation of anomalies and additional external pressures.

During the Soviet period, the nomads were partly settled in purpose-built villages. The collectivisation of herding and hunting was completed during the 1960s in this region, transforming the Evenki economy. They became employees of state farms (Ru. sovhoze) while their reindeer were turned into the property of these institutions. Fur and food hunting were intensified, as well as reindeer herding, to allow for greater levels of meat and fur production. After the collapse of the Soviet Union and the concomitant economic crisis, the closure of state farms meant that the hunter-herders stopped receiving salaries. From the beginning of this crisis in the early 1990s, many Evenki in the region concerned returned to their former nomadic lifestyles and recovered traditional forms of reindeer herding and sustainable hunting, thus restoring the subsistence economy: they also reorganised their pastures and nomadic roads (Lavrillier 2005).

Nowadays, the highly mobile nomadic Evenki live in the taiga and practise a "traditional" type of reindeer herding specific to this biome: they are highly dependent on hunting for food and furs and use small herds of reindeer for transportation. This implies a dual economy and a dual logic of subsistence between hunting and herding, with seasonal interplay between the two. Hunting is carefully planned so that every species can breed successfully (among others Lavrillier 2005, 2011a). The reindeer are owned by "stock companies" (former state farms) that pay salaries for pastoral work, "clan communities" (indigenous mini-companies recognised by the Russian government) that receive a fee for each living reindeer, or "private herders" who lack administrative structures, official recognition, and regular incomes.

60 Another very important point is that the Evenki, like all Siberian peoples, have no property rights to their ancestral lands. In the Russian Federation, only land surface can be owned by an individual or organisation: the rest is the exclusive property of the state. Thus, if there are natural resources present in the subsoil, the property is not protected against extractive industry activity. The reindeer-herding stock companies and clan communities can be allotted a piece of land (around 200-500 ha/herd) for free (or for rent according to the 2009 land law) for between five to 25 years: they cannot block the establishment of extractive industries. In contrast, private herders have no rights at all to the lands where they have nomadised for several generations.

61 The Southeastern Evenki have been in contact with extractive industries (gold and coal mines) since the end of the $19^{\text {th }}$ century; however, recent developments directly linked to the worldwide interest in Arctic and Subarctic natural resources have seen the substantial growth of industrial projects (pipelines, dams, roads, and railways) either directly on nomadic areas or close to them. In 2017, from the six villages and their nomadic zones in the region under study, only one is more or less entirely preserved from industrial invasion, while three of them are surrounded by, or even entirely embedded within, highly industrialised and polluted mining sites.

In this context, climate change brings additional pressures to bear, such as various anomalies and "extreme weather events". For several decades, the Evenki have been noticing climate and environmental changes (see below); however, these changes have been increasing more rapidly over the last six to 11 years (according to a socioanthropological study of climate and environmental changes led between 2006 and 2012). Indeed, while in 2006 a single word in Evenki summed up the main trend of 
weather change in indigenous narratives (okollen, meaning "it is getting hotter", not only "warmer"), from 2013 the vernacular expressions reveal an increasing anxiety (see below ${ }^{16}$.

In the framework of global climate change, what kind of extreme events do the Evenki observe and what is their concept of an "extreme event"?

\section{What is the Evenki perception of an "extreme event"?}

For this question, one must pay attention from which angle the term "extreme" is viewed. For instance, it is recurrently written that Siberian peoples live in an "extreme environment" and experience "extreme weather", but this is from the point of view of Western societies/science. For Siberian peoples, their climate, considered "extreme" by the West, is a norm (e.g. non-extreme). But this does not mean that indigenous peoples do not have their own understanding of "extreme weather", or "extreme event": they certainly do. (see below the expressions like Evk. davdavse).

Thus, what is generally considered as an extreme weather event by the Western sciences is often not seen as such by the Evenki nomads and what the nomads consider "extreme" is not seen as such by scientists. For instance, forest fires are not often an extreme event for nomads, since (in contrast to villagers) they can avoid them by moving away. Thanks to their mobility, herders can also manage flooding easily. In contrast, while the hot and dry summer of 2015 was easily borne by villagers, it was an extreme event for nomads: almost all of the calves born in 2015 perished because the vegetal cover dried up. The torrential rain and cold of the summer of 2016 was a truly "extreme event" for the villagers because houses and vegetable gardens were flooded and the harvest was frozen. The nomads were not affected: the calves survived this cold summer well. The fact that there were fewer insects meant that they spent more time grazing than standing in the camp close to the smoke fires made to protect them against mosquitoes and horseflies. In the same way, earthquakes are not a problem for the nomads because they lack large buildings. Other events that would usually be considered extreme, such as snow in the middle of the summer, have no specific consequences for the nomads. It is remembered as a rare and interesting event, but not as "extreme". This shows that the perception of an extreme event varies according to lifestyles and economic activities, even within a single people and a single region.

Emic "extreme events" are determined as such according to a vernacular understanding of norms and anomalies and their impacts on society. From daily observations made according to their indigenous knowledge and cognition, the Evenki identify normal and abnormal modifications occurring in their environment and climate. As we will see, their observations and analysis of change are very systemic, focusing not only on one single element of the natural environment, but also on the interactions between many elements (for instance, between temperatures, snow cover, vegetal cover, rivers, etc.). As we have seen, the Evenki have their own system of weather/climate observation and prediction. This system consists of "norms" which, to a certain extent, are flexible when it comes to annual variations. Such flexibility is concerned with the date of the appearance of a seasonal event, admitting a difference of around two weeks for the snow cover to completely melt, to give one example. It also refers to expected temperatures (with the admissible variation ranging from a difference of $15^{\circ} \mathrm{C}$ to one of $20^{\circ} \mathrm{C}$ ) or the quantity of a precipitation (in days of rain/ 
snow, in snow/river depth). In cases where the variations are too significant or too regular, they are considered "anomalies" (Fig. 4). For example, if the cold winter is delayed by two weeks over the course of three years, it is considered an "anomaly", but if this anomaly is continually repeated or if the delay goes over this limit, it is considered "extreme weather" (Lavrillier et al. 2016, pp. 113, 119) (Fig. 5) ${ }^{17}$.

As we will see, the Evenki have noticed different sets of anomalies (be it the yearly repetition of the same anomalies, an anomaly which lasts too long, or the accumulation of anomalies of different types, etc.) that they consider the equivalent of an "extreme weather event" in the usual Western meaning of the term.

Extreme weather event: weather conditions and weather-related events that are rare at a particular location and time or can cause significant impacts. (Morss et al. 2011)

Thus, the Evenki perception of an "extreme weather event" (mostly combined or repeated anomalies) seems to contrast with the perception of the western sciences, which generally consider an extreme event to be a one-off thing, like flooding, a hurricane, etc. (Fig. 5).

Figure 5. Western and emic understandings of an "extreme weather event"

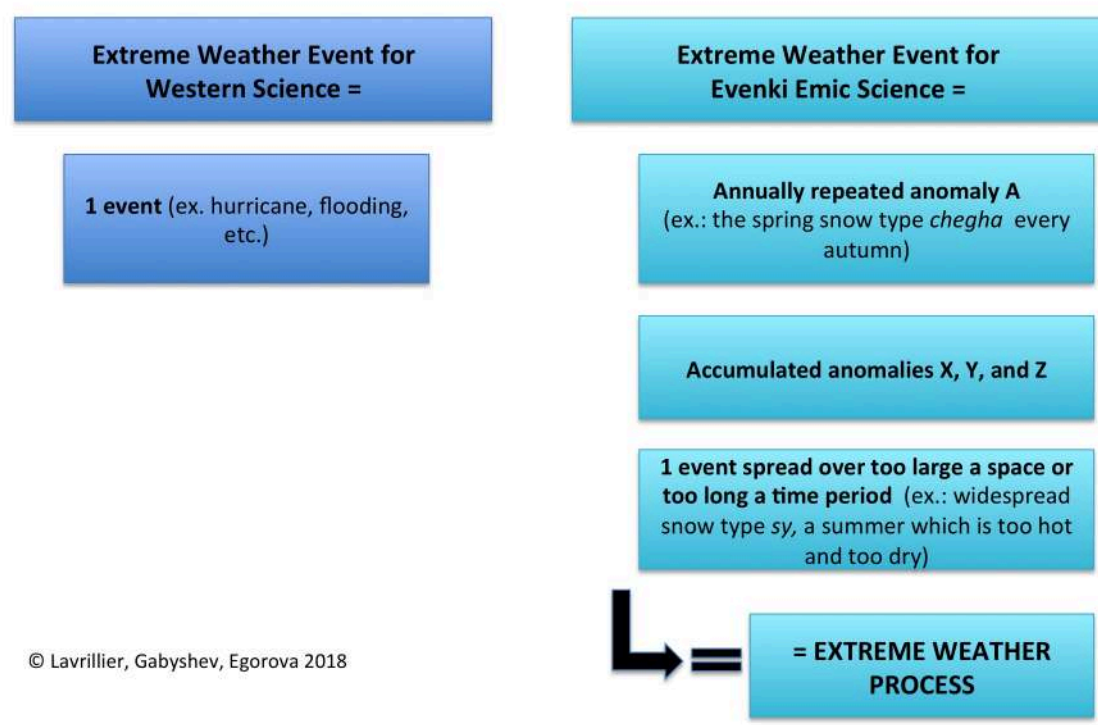

\section{(C) A. Lavrillier, S. Gabyshev and L. Egorova, 2018} So, for the Evenki we argue that it would be more appropriate to use the expression
"extreme process". Our analysis reveals the distinction within the Evenki perception of process" and the "hybrid extreme process" (see below). 


\section{An emic classification: from anomalies to a "broken environment"}

71 As shown by Gabyshev and Lavrillier's analysis of interviews gathered between 2011 and 2018, the Evenki (nomads and settled) use the following vernacular expressions to discuss the degrees of distinction between "anomalies" and different "extreme processes". They are related to the degree of adaptability or vulnerability of society as it is perceived by the nomads.

Thusly, to talk about anomalies occurring in a single year, the Evenki use the word "strangely", "abnormally" (Evk. dikte) and a relevant verb. Take, for example, dikte imannadieren - "the snow period is abnormal" (i.e. it has exceeded the variations set by vernacular norms).

It is said that humans "adapt" (Evk. tatyvkil). This comes from tatta-da, meaning both "to get used to" and "to learn intellectual and practical knowledge ${ }^{18 "}$ ". In the present form, it means "they are able to find a way to act in the face of new pressure, of doing that can become a habit".

74 To discuss repeated anomalies over the course of several years, accumulated anomalies, or overly intensive anomalies that lead to social difficulties (i.e. "extreme weather process"), they use the vernacular word manak ("any old how", "out of sync") and a verb. Consider, for instance, the expression manak imannadieren - "the snow period is out of sync".

It is said that then that humans "are making a perennial effort to adapt" or "they are constantly endeavouring to find a way to face new pressures" (Evk. tatchediere).

To express the repetition and accumulation of anomalies at a higher level of intensity in different domains of the natural environment (i.e. the so-called "extreme natural process"), they say: "the natural environment is broken" (Evk. Bugha ukchapcha) or "the natural environment has gone astray" (Evk. Bugha kaicha). The latter infers that it has become difficult, if not impossible, to survive. The emic criteria "extreme", in addition to an accumulation of anomalies or a considerable anomaly, is connected to the intensity of the impact on economic life and society's survival.

77 In this case (and also in face of what we call an "hybrid extreme process", see below), the Evenki concerned use vernacular expressions referring to vulnerability that derive from the verb dab-da meaning "to give up", "to lose", "to be defeated" (Vasilevich 1958, p. 101). In the dialects we worked with in the field, there are several variants related to degrees of vulnerability and the degree of the "extremeness" of the conditions: "it is impossible to act" (dabdy), "completely impossible to act" (soma dabdy), "I/we feel now like giving up" (dabdymo!), and, finally, "the context forces me/us to give up/to feel defeated" (davdavse!), e.g. "the context forces me/us to stop fighting for survival/stop maintaining a life style". The latter expresses the very emic criteria "extreme", in the sense of a final limit to possible continuation (see below, and Fig. 9). It is thus not surprising that most of the interviews gathered from 2016 spontaneously start with "Our life style and culture will end soon, everything leads to this".

Before further analysing the Evenki concept of an "extreme event", let us now describe what the nomads notice. They have observed that the coldest part of the winter is now around two months shorter than it was 30 years ago: it is also warmer than it was then, which means the snowy season is getting much shorter. They also complain that the summer no longer consists of a good balance between rainy and sunny days, since it is 
mainly "extreme": it is either too hot and dry (like in 2015), which causes widespread and prolonged forest fires, or too rainy and cold, which may lead to flooding (like in 2016). In addition, the Evenki link the warming to a general increase in forest fires (Lavrillier 2013, Lavrillier et al. 2016, p. 115).

The following illustrates well what the Evenki mean by "the natural environment is broken". They relate shifts in the climate with changes observed in the flora and wild fauna. They have noted the extinction of some plant and animal species and the appearance of new birds and insects. The Evenki are particularly worried about a considerable increase in predator populations and a decrease in the number of wild reindeer and elk: the extent of the latter may mean there are no longer enough of them to feed the nomadic population. They have also noticed that the annual migration patterns of wild reindeers have changed. The Evenki link the accumulation of anomalies to major unexplained changes affecting their domestic reindeer: new insects (causing infection in the antlers and, from 2012, an increase of the tick-borne encephalitis virus), sudden death, and unknown parasitic illnesses (Lavrillier 2013) (Fig. 6).

Figure 6. Accumulated anomalies in local biodiversity observed by the Evenki, 2012-2016

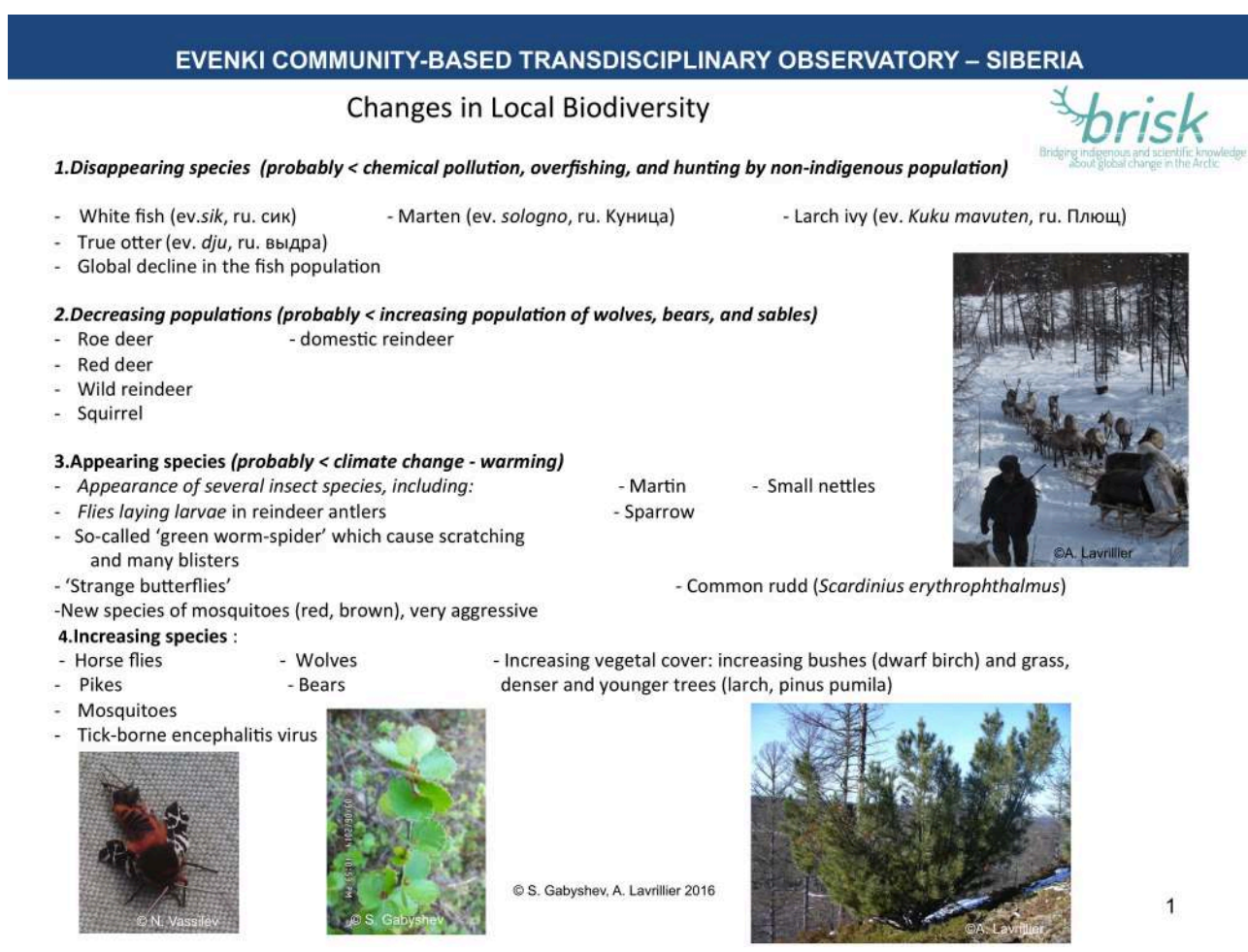

(c) S. Gabyshev and A. Lavrillier, 2016 
the year (seven-ten months), the anomalies the Evenki are most worried about are disruptions to the snow cover, which we will now focus on.

\section{Some "extreme weather processes": accumulated disruptions of the snow cover}

The Evenki have noticed an accumulation of anomalies in the snow cover. Gabyshev and Lavrillier have identified a "disruption of the snow cover" that threatens, among other activities, sable hunting and thus the subsistence and wellbeing of society. Several types of anomalies make up this disruption: 1) the delayed installation of the snow cover; 2) different types of snow do not arrive when they are expected; and 3) there are extremely frequent anomalies in the depth of the snow cover. This disruption of the snow cover triggers many challenges that threaten economic activities (hunting and herding), protection against predators, and freedom of movement; in other words, they pose a threat to the very subsistence of this nomadic society (Lavrillier et al. 2016). Among the Nenets in Western Siberia, frequent disruptions of the snow cover are also recognised as a serious threat to reindeer-herding communities (Bartsch et al. 2010).

As stressed by the Evenki nomads, the consequences of the accumulation of frequent anomalies force them to adapt continually. With respect to the concepts of "adaptation", "resilience", and "vulnerability" that are omnipresent in the studies on Arctic climate change (Berkes \& Jolly 2001, Ford et al. 2006, Oskal et al. 2009, among many others), Evenki narratives and rituals offer contradictory perspectives that range from optimistic beliefs to millenarian predictions or pessimistic expressions (see above). Nonetheless, their economic practices demonstrate that the Evenki are highly adaptable; as the Evenki themselves repeat, "for ages we have been adapting and coping, and we will continue to do so as long as possible" (cited in Lavrillier 2013). As shown by our study, the key elements essential for adaptation are landscape, reindeer, and TEK: "As long as we have reindeer, the landscape, and knowledge, we can adapt ${ }^{19}$ ". Nevertheless, the interviews gathered in the winter and summer between 2016 and 2018 contain complaints about the increased frequency and unpredictability of anomalies of varying intensity, thereby revealing fragility in this generally resilient people (see below).

An important element for further analysis is that the Evenki mainly employ their mobility to face these anomalies: they can entirely modify their annual nomadic routes and move them 150-300 km away (as they did in the 1990s and in 2018). This high level of mobility is made possible by the following facts. Even if some territories are allotted to reindeer husbandry stock companies and clan communities, and even if private herders have no land rights, traditional nomadic rules of land use are still active, thereby allowing (when still possible) for the almost entirely free circulation of nomadic groups. Space is not considered by the Evenki to be private property: herding and hunting spaces are shared, although this arrangement usually follows a prior agreement made annually ${ }^{20}$.

The delayed installation of the snow cover triggers challenges to hunting and herding. The consequence of this change is that Evenki hunters lose an entire month of hunting and thus a considerable amount of sable furs and income. The loss of a month represents a substantial decline in purchasing power. They adapt by changing their hunting techniques. Sometimes, the combined effects of a shortened winter and snow cover disruptions on hunting patterns threaten reindeer herding. The short hunting period forces the hunters to spend almost all their time tracking sable rather than 
surveying the reindeer herd: equally, the very thin layer of snow allows the reindeer to move considerable distances in various directions. These two consequences increase the risk that the herd might be lost (for more details, see Lavrillier et al. 2016, pp.115-119). The delayed installation of the snow cover is also disturbing mating and calving schedules.

One of the most important anomalies in the creation of an "extreme process" is the disruption of the evolution of the snow cover: different types of snow do not arrive when they are anticipated. According to our study, Evenki terminology includes 25 types of snow that must appear according to a chronological norm (although this norm does admit variations). Each of these snow types can either enable or threaten the economic activities of the Evenki (Lavrillier \& Gabyshev 2015, 2017, pp. 243-253, Lavrillier et al. 2016). They can change one seasonal state into another (Lavrillier \& Gabyshev 2017, pp. 255-278), and in a different pattern than in the past. The disruption of the snow cover can have severe and dramatic consequences. Here are some examples from the many observed strong anomalies.

For instance, the snow type chegha is normally expected in the spring, but it abnormally appeared at the beginning of the snow period in 2015-2016. The installed snow was humid because of the warm temperature. Temperature jumps and freezing transformed this wet snow into chegha, i.e. a layer of asphalt-like snow cover. As a result, it threatened the yearly income of the nomads: the sable were able to run away very quickly from the hunters on the hard surface, while the hunters and their reindeer moved very slowly and with difficulty through the hard and heavy snow. The Evenki adapted by changing their hunting techniques (Lavrillier et al. 2016). The same phenomenon also challenged the herd's access to lichen, so the Evenki moved to lands where they could find the snow types expected in this period.

Another example is the snow type sy - a layer of "snow ice" attached to the ground within which the vegetal cover is embedded. This type of snow, considered an anomaly if it still exists during the winter (like in 2014-2015), results from a thin initial layer of snow that then melts during warm days: rapid and abnormal freezing transforms this into ice that embraces the vegetal cover, thereby limiting the extent to which domestic and wild animals can access it. This abnormal type of snow can trigger massive loss of reindeer (Lavrillier et al. 2016). Herders can avoid catastrophe by moving to places without sy.

89 A third example occurred in January 2014-2015, one which created many problems with transportation. Be it by sledge, snowmobile, or skis, all transport became almost impossible and extremely dangerous, with an average temperature of $-25 /-50^{\circ} \mathrm{C}$. Many herders/hunters frequently got stuck in the middle of their trips, risking their lives: they had to spend hours digging reindeer sledges or snowmobiles out of the humid, porridge-like snow. A trip usually made in three hours was taking around 15-20 hours. This occurred because of the lack of strong cold $\left(-45 /-55^{\circ} \mathrm{C}\right)$, which usually transforms the dry and soft snow (Evk. duiukun) into icy, seed-like flakes (Evk. buldo). This snow type provides the necessary firmness for the establishment of snow roads. In addition, an abnormally warm snowstorm deposited an excessively deep layer of fluffy and rather wet snow (Evk. debdeme - a snow type usually found in the late spring).

90 As in the winter of 2014-2015, the lack of strong cold and the abnormal warming (even at night) meant the Evenki were blocked into their camps because they could not create snow roads: the strong cold at night normally freezes the snow on the surface of the 
roads, creating a hard layer of snow that allows the nomads to move for hunting and herding.

91 Finally, during the winter of 2015 , low temperatures of $<-50^{\circ} \mathrm{C}$ were followed by abrupt warming: this weakened the ice on the rivers, making them susceptible to breaking under reindeer sledges or snowmobiles (Lavrillier \& Gabyshev 2015).

During the last eight-ten years, there have been very frequent strong anomalies in the depth of the snow cover. This seriously challenges the economic activities and survival of the Evenki nomads.

The Evenki have their own system for measuring snow depth: "up to the knee" (Evk. elekin) is the ideal depth for herding and hunting activities; "up to the ankle" (Evk. suaban) is an anomaly in the winter; "up to the calf" (Evk. arban) and "up to the thigh" (Evk. sungta) are considered manageable; while "up to the torso" (Evk. sugntakun) is considered too deep for hunting and herding activities.

The snow depth is a crucial factor for the access of the reindeer to grazing grounds. The Evenki lead their herds to places where there are bearable snow conditions. Here again being mobile is the most important tool for adapting. The Evenki use the different snow depths. Thin layers of snow (Evk. suaban and arban) are used in the autumn for sable hunting with dogs. In contrast, deep snow, sungta, is used to keep reindeer gathered in one area and ensure that predators are kept at a distance: wolves cannot cross areas where the snow is deep.

Anomalies in the snow depth can have harsh consequences. A snow cover which is too deep threatens sable hunting, transportation, and thus household purchasing power (Lavrillier et al. 2016).

The presence of a very thin layer of snow (arban or suaban) throughout the winter, like in 2011, leads to an "extreme process" in different domains. In this year, it was very cold and the reindeer moved very far in various directions, weakening as they did so. Thus, herders had problems with keeping the herd together and predators found it easy to attack it.

Sometimes, the Evenki see both the direct and indirect negative consequences of snow depth on the development of vegetal cover and the presence of fur and food game ${ }^{21}$.

\section{“Extreme nature processes": weather, vegetal cover, and predators}

As another example of the systemic perception of extreme processes, the following case shows how the accumulation of anomalies and external pressures interact. The depth of the snow is also important indirectly because, according to the nomads, it has consequences for the vegetal cover and, later, the behaviour of predators. Thus, anomalous excessively deep snow covers, which have occurred since 2013, can lead to an overgrowth of the vegetal cover that in turn opens the way for wolf attacks on the herd. The Evenki know that the snow protects the vegetal cover and that deep snow irrigates the vegetation by melting slowly: this boosts the growth of vegetation. In contrast, a thin layer of snow melts quicker, which lets the frost destroy seeds. So, anomalies of increasing snow depth will generate a dense and bushy vegetal cover, a landscape in which wolves can hunt easily. This enhances the threat of predator attacks on reindeer. 
Let us note that, in terms of indigenous cognition, we have here science-like emic hypotheses that allow for predictions to be made several years in advance (similar to modelling). We also demonstrated the existence of TEK hypotheses that model past and present transformations of the landscape via climate change over several dozen years (Lavrillier \& Gabyshev 2017, pp. 438-444). These hypotheses focus on the interactions between elements that the Western sciences usually study separately.

An accumulation of weather anomalies, when combined with external pressures from the environment, creates "extreme nature processes". During our field studies from 2006-2012 and from 2013-2018, the theme of predators reached a crescendo in interviews and narratives. In all the interviews gathered from 2016 in the six villages under study, the growth in wolf and bear populations was recurrently declared to be "the number one problem exterminating reindeer herding in the region, [a problem] in the face of which it is very difficult to adapt". As we will see, despite the huge damage inflicted by the development of extractive industries, predators are still seen as the most important problem for reindeer herding.

01 From 2006, several herds entirely disappeared because of wolf and bear attacks. Other herds have lost from between a quarter to two thirds of their reindeer; furthermore, these losses are increasing annually. Bear and wolf attacks on humans are becoming more frequent each year in nomadic areas, villages, and towns. Sometimes these attacks have reached such an extent that the nomads decided to modify their ritual gestures in order to avoid leaving meat and bone offerings in their encampments (Lavrillier 2008). The nomads have noticed that the behaviour of predators has changed, as was expressed in the following typical statement:

Before we had a kind of agreement with predators: humans leave them some territories for hunting and predators leave people and their reindeer in peace and almost don't touch them. Now predators have really become too numerous, and they are often sick and hungry. They are now behaving in a completely different manner than in the past: they have become insolent, aggressive. They are walking directly onto the roads and into camps of humans, they are not afraid of humans anymore. They do not have enough wild game to hunt, so they attack the reindeer herds. We cannot do anything against them: they are too intelligent, it is almost impossible to hunt them ${ }^{22}$.

In the past, the Soviet state regulated wolf populations by hunting from helicopters, but this has not been done since the 1990s in the Amur region and very rarely in Yakutia (although there have been some improvements during recent years). Before the mid-2000s, the Evenki placed poison within the carcasses of attacked domestic reindeer to reduce the predator populations. This was forbidden by international ecological organisations. According to the Evenki worldview still active in the minds of these nomads, predators (Evk. beingal) are the ancestors of humans and are deeply respected; however, predators today do not allow reindeer herds to develop or be maintained. In the winters of 2015 and 2017, several massive attacks occurred: no more than two or three wolves killed 15 to 30 reindeer within two days (Fig. 7). Those whose herd was the victim of such an attack say:

How can we continue to live in such conditions? We cannot face it! How can we maintain reindeer herding? The wolves are the worst because they tear out the reindeers' throats and leave their prey dying, they do not even eat them! - Our reindeer die for nothing! 
Figure 7. Reindeer killed by wolves from the 30 killed over two consecutive nights

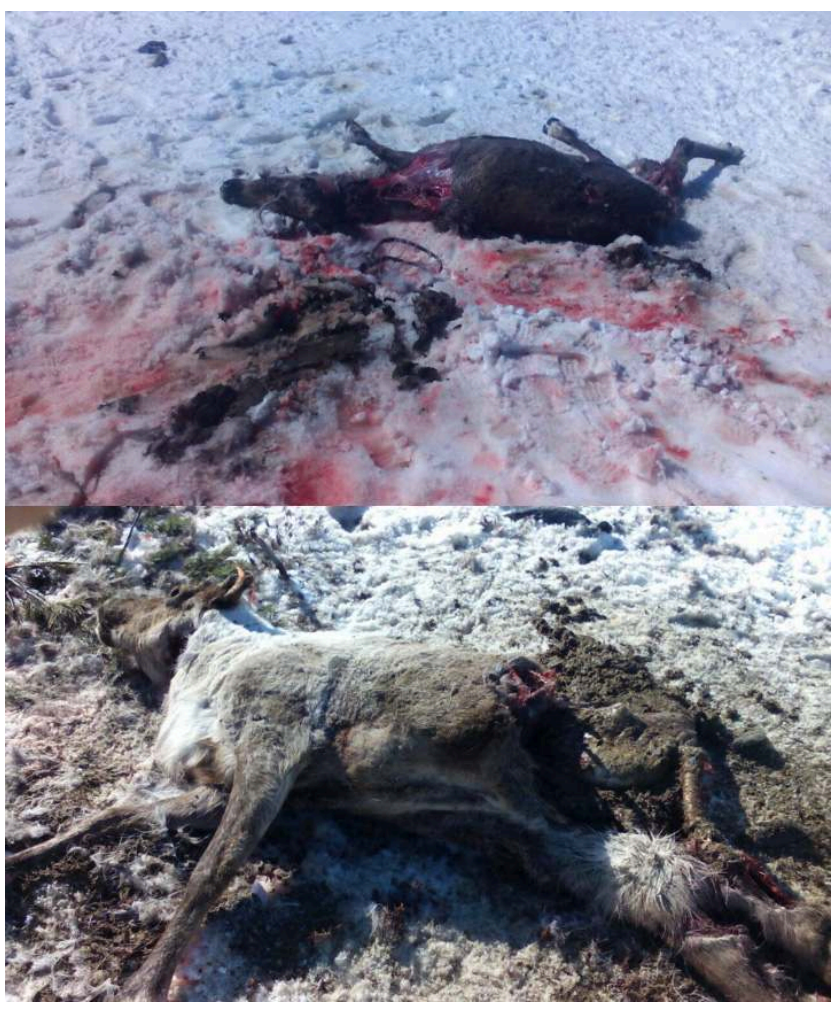

The herder owner of these reindeer was so shocked that he took some pictures with his smartphone. (c) M. S. S., herder in southern Yakutia, April 2016

\section{The "hybrid extreme process" of accumulated weather anomalies, predator populations, and industrial development}

103 As we have seen above, the anomalies incurred by climate change are related to problems caused by predators; for instance, when a thin snow cover or dense vegetation linked to repeated instances of an abnormally deep snow cover allow for wolves to easily hunt the heard. Similarly, late installations of the winter snow and abnormally early springs shorten the snow period and thus give the wolves longer to hunt.

104 In addition, climate change is linked to an increase in the number of fires, which reduces the amount of pasture available for domestic reindeer and endangers their health. The fires reduce the natural space available for predators, which forces them to migrate into other areas (often the same lands occupied by the nomads): this triggers an increase in the number of predators on herding lands and the killing of domestic reindeer (Lavrillier 2013, p. 263).

105 Sometimes, climate change anomalies and issues with predators combine with the invasion of extractive industries. This again causes an "extreme process" to occur, but it has a hybrid character, since it includes pressures caused not by the natural environment but by human activity; we call this a "hybrid extreme process".

106 For further analysing the "hybrid extreme process", let us briefly describe a crucial element. We have seen that the Evenki can adapt thanks to mobility, but this mobility is threatened by the development of extractive industries on the reindeer pastures. As 
shown in Gabyshev's diagram (Fig. 8), many hunting lands and pastures have been invaded by extractive industries, which poison and churn up the ground. This leads to almost irreversible environmental damage, a considerable reduction in nomad mobility (one of the main tools for adaptation), and negative consequences for Evenki society and culture ${ }^{23}$.

Figure 8. An Extreme Process: Ecosystem Services Threatened by Extractive Industries

\section{Extreme Process: Ecosystem Services Threatened by Extractive Industries}

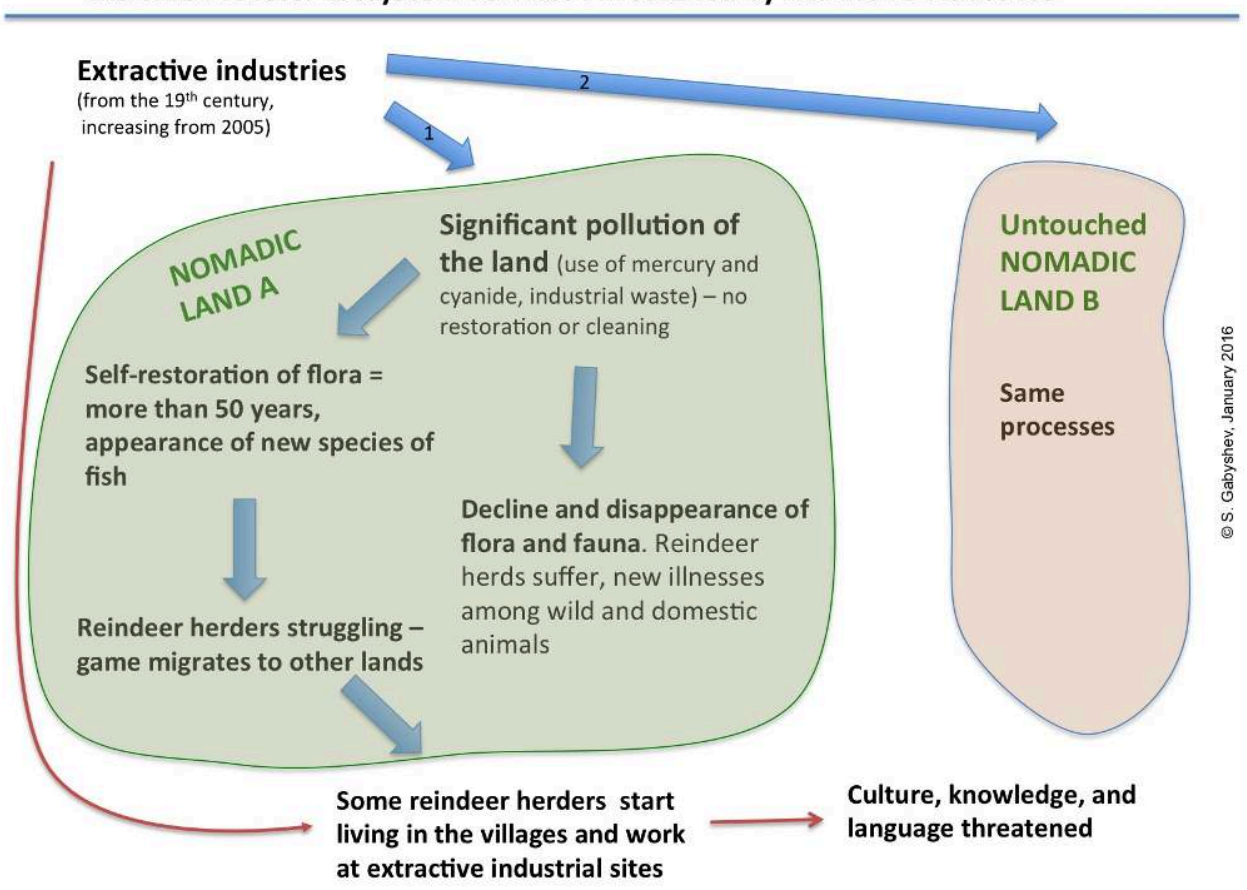

(C) S. Gabyshev 2016b

In addition to these destructive effects, during the very hot and dry summer of 2015 , an abnormal increase in the wolf population during the preceding winter meant that the reindeer herders needed to keep the herds close to villages and towns. They were thus positioned close to industrial mining zones, where poor and polluted grazing lands that had already been dried up by the heat wave threated the reindeers' health. This resulted in the death of most calves from that year (Lavrillier \& Gabyshev 2015). In the summers 2016 and 2018, the interviewed herders complained that the wolves were moving into their herds even when they were located close to villages and towns. The latter is a perfect example of a "hybrid extreme process". In these conditions, it is impossible to develop or even maintain the reindeer herd, which seriously threatens this nomadic society.

\section{Conclusion}

When you ask a Evenki to define the most typical "extreme event", they immediately designate two issues: the disruptions of the snow cover and predator population growth. The massive loss of reindeer due to predators exceeds the numbers of anomalies that the nomads can manage. In addition to the accumulation of climate 
change anomalies, economic crisis, industrial development (which also reduces nomadic space), and the absence of land rights (which complicates access to ancestral lands), the disaster provoked by predators reveals vulnerability. In the gathered interviews, herders repeatedly said:

We can adapt to climate anomalies, industrial development, new illnesses, and economic crisis, but how can we protect our herd against predators?

With regards to the emic science of climate, Evenki emic climatology and TEK are rich, containing as they do elaborate typologies and theories, which produce hypotheses focusing on the many interactions between the climate, landscape, flora, and fauna.

The Evenki notion of an "extreme process" proves the systemic character of the emic understanding of climate change. Its scope is further extended by the inclusion of industrial development. We can compare this with the most recent results from Western climatology and atmospheric physics, which prove that anthropic activities (including industrial development) are the main factors that trigger local and global climate changes (IPCC 2014a, p. 46).

Thanks to its systemic approach, the Evenki perception of an "extreme process", complements the IPCC's conclusion quoted above, since it stresses the interactions of accumulated anomalies in the same or different domains of the climate and the entirety of the natural environment, as well as human factors. When the negative consequences provoked by external non-natural factors (those which do not emerge from the natural environment) are added to this, it becomes a "hybrid extreme process". The latter not only poses challenges but also seriously questions the resilience of this nomadic society: thus it is not surprising that vulnerability is now being revealed and that from 2016-2018, the Evenki themselves often refer to the emic notion of "vulnerability" or "extremeness" (Evk. davdavsy) (see above), meaning literally "the context forces me/us to give up, to feel defeated", e.g. "it forces me/us to stop fighting for survival", thus expressing the idea of being close to a final limit.

112 As such, this study reveals the existence of an emic characteristic of the "extreme": this does not have a singular meaning but is rather spread along a spectrum (detailed above) between two main points. First, manak (e.g. "out of sync") designates a set of conditions that causes significant consequences for Evenki society, to which it then endeavours to adapt; second, at the extreme end of the spectrum is davdavse (the "hybrid extreme process"), which designates conditions that push society towards a breaking point at which it can no longer adapt. The criteria determining such degrees are, for the Evenki, the intensity of the impacts and the capacity of their society to further adapt.

113 We gathered in the diagram below (Fig. 9) different elements of the emic notions of "extreme process", TEK, adaptation, and vulnerability. 
Figure 9. Articulation between norms (known and unprecedented), anomalies, extreme processes, engaged knowledge, and emic notions of adaptation and vulnerability

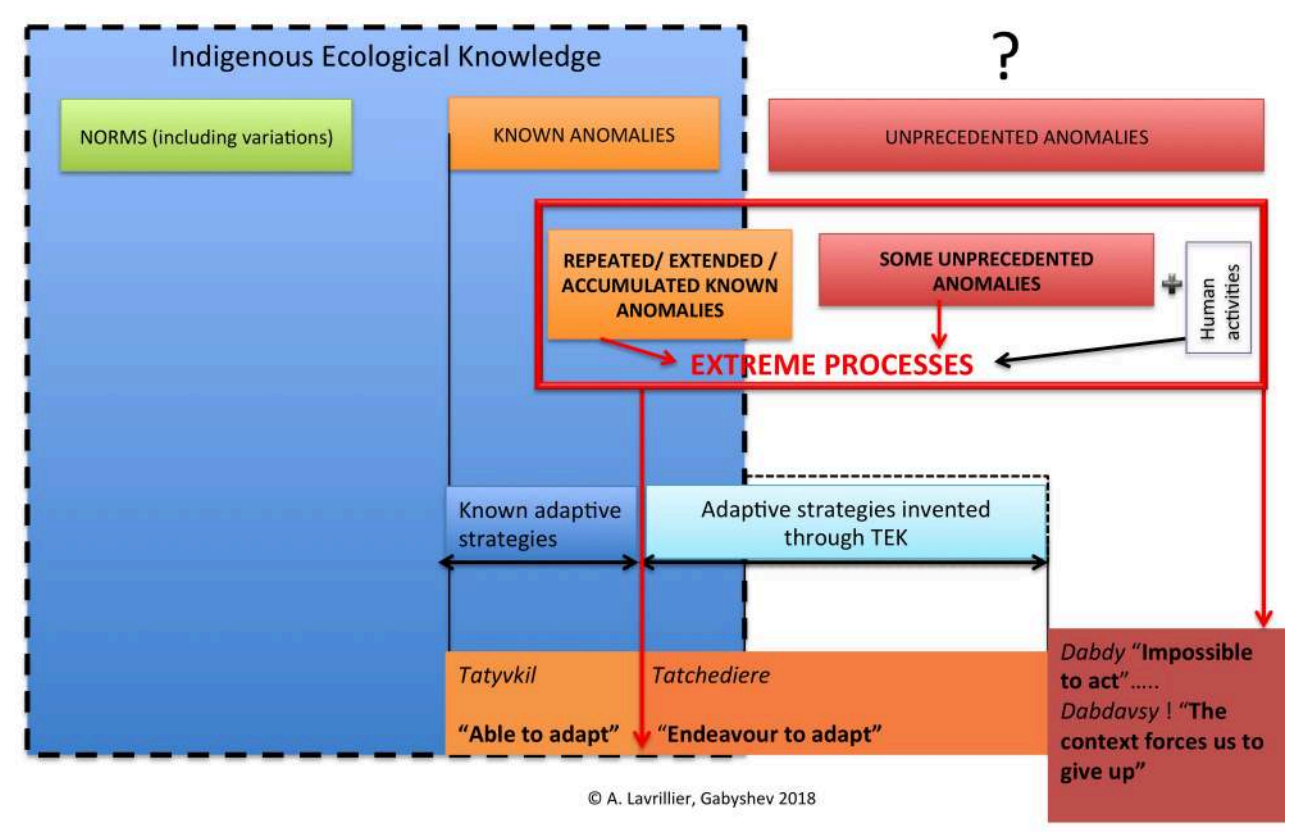

(c) A. Lavrillier and S. Gabyshev, 2018

This analysis of an emic understanding of "norms", "anomalies", and "extreme events" could help us to understand the significance of TEK for the climate sciences and policy.

TEK, or, in other words, the "emic science of climate", provides valuable input for climate studies in different ways. It proves the importance of studying climate change on smaller scales, since even those anomalies considered small by environmental scientists (and which are thus neglected) seriously affect local communities (Lavrillier \& Gabyshev 2017, pp. 39-40). Some TEK typologies are more detailed and elaborate than those used in the environmental sciences (regarding snow and ice in particular $\left.{ }^{24}\right)$.

TEK focuses on significant interactions between climate and the entire environment, some of which are apparently ignored by the sciences. This research, as well as similar research quoted in this paper, proves the richness of data and analysis co-produced in community-based observatories and the importance of unbroken observation by/with indigenous peoples. Furthermore, TEK and the social sciences are complementary, since their combination allows us to focus on the socio-economic impacts and cultural costs of all climate/environmental anomalies and "extreme processes", most of which remain unidentified on an international level (like the predator issues for instance).

TEK can contribute to climate change and/or environmental policy. At our humble level, this Evenki community-based observatory was selected to publish in the report of the Indigenous and Local Knowledge Task Force for the IPBES report for Europe and Central Asia (UNESCO, UNEP, UNDP, FAO) (Lavrillier et al. 2016). However, despite the international conventions on environment and climate mentioned in this paper, the question about officially recognising TEK as a science and indigenous observers as negotiation interlocutors remains open.

All of this justifies engaging TEK in the climate and environmental sciences. However, as we experienced, for a successful collaboration between the Western and emic 
sciences it is first necessary to document TEK in depth as a system (if it is such a thing) in order to highlight its typologies, concepts, and theoretical dimensions: this takes many years of effort and patience. Emic science can complement several Western environmental and social sciences. Indeed, we have seen that an emic science conceptualises not only the natural environment in its normal state, but also "anomalies", "extreme events", and the degrees of vulnerability faced by society. Therefore, Evenki emic science encourages the Western sciences to revisit the notion of "extreme" more generally and according to the viewpoints of various cultures and lifestyles.

\section{BIBLIOGRAPHY}

Barnard, A. \& J. Spencer (eds) 2005 Encyclopedia of Social and Cultural Anthropology (London, New York Routledge).

Bartsch, A., T. Kumpula, B. C. Forbes \& F. Stammler 2010 Detection of snow surface thawing and refreezing in the Eurasian Arctic with quik-SCAT: implications for reindeer herding, Ecological Applications 20(8), pp. 2346-2358.

Berkes, F. 1999 Sacred Ecology. Traditional Ecological Knowledge and Resource Management (Philadelphia, Taylor \& Francis).

Berkes, F. \& D. Jolly 2001 Adapting to climate change. Social-ecological resilience in a Canadian Western Arctic community, Conservation Ecology 5(2), p. 18. [online, URL : http://

www.consecol.org/vol5/iss2/art18/, accessed 28 February 2017]

Bogoslovskaia, L. S., B. I. Vdovin \& V. V. Golbtseva 2008 Izmeneniia klimata v regione Beringova proliva. Traditsionnnye i nauchnye znaniia [Climate change in the Bering Strait region. Integration of scientific and indigenous knowledge], Èkologicheskoe planirovanie i upravlenie 3-4(89), pp. 36-48.

Bourdieu, P. 1984 Homo Academicus (Paris, Les éditions de Minuit).

Burgess, P. 1999 Traditional Knowledge. A Report Prepared for the Arctic Council Indigenous Peoples Secretariat, (Copenhagen, Arctic Council Indigenous Peoples' Secretariat).

Collins 2016, Free Online Dictionnary, [online, URL: http://www.collinsdictionary.com/dictionary/ english/science, accessed 30 October 2016]

Cincius, V. I. 1975 Sravnitel'nyi slovar' tunguso-man'chzhurskih iazykov [A comparative dictionary of Tungus-Manchu languages], I (Leningrad, Nauka).

Crate, S. A. 2008 Gone the bull of winter? Grappling with the cultural implications of and anthropology's role(s) in global climate change, Current Anthropology 49(4), pp. 569-595.

Crate, S. A. \& A. N. Fedorov 2013 A methodological model for exchanging local and scientific climate change knowledge in northeastern Siberia, Arctic 66(3), pp. 338-350.

Fabian, J. [1983] 2014 The Time and the Other. How Anthropology Makes its Object (New York, Columbia University Press). 
Federal State Statistics Service 2010 All-Russia Population Census (in Russian), retrieved 29 June 2012 [online, URL: http://www.gks.ru/free_doc/new_site/perepis2010/croc/

perepis_itogi1612.htm, accessed 6 October 2016]

Forbes, B., F. Stammler, T. Kumpula, N. Meschtyb, A. Pajunen \& E. Kaarlejärvi 2009 High resilience in the Yamal-Nenets social-ecological system, West Siberian Arctic, Russia, Proceedings of the national academy of sciences of the united States of America 106(52), pp. 22041-22048.

Ford, J. D., B. Smit \& J. Wandel 2006 Vulnerability to climate change in the Arctic. A case study from Arctic Bay, Canada, Global Environment Change 16, pp. 145-160.

Gearheard, S., L. Kielsen Holm, H. Huntington, J. M. Leavit, A. R. Mahoney, M. Opie, T. Oshima \& J. Sanguya 2013 The Meaning of Ice. People and Sea Ice in Three Arctic Communities (Hanover, New Hampshire, International Polar Institute Press).

Gearheard, S. \& J. Shirley 2007 Challenges in community-research relationships: learning from natural science in Nunavut, Arctic 60(1), pp. 62-74.

Golovnev, A. V. 2017 Challenges to Arctic nomadism. Yamal Nenets facing climate change-era calamities, Arctic Anthropology 54(2), pp. 40-51.

Helander-Renwall, E. 2005 Composite report on status and trends regarding knowledge, innovations and practices of indigenous and local communities, Biological Diversity in the Arctic [online, URL : www.UNEP/CBD?WG8J/4/INF/3, accessed 28 February 2017].

Huntington, H. P. 1998 Observations on the utility of the semi-directive interview for documenting traditional ecological knowledge, Arctic 51(3), pp. 237-242.

Huntington, H. P., T. Callaghan, S. Fox \& I. Krupnik 2004 Matching traditional and scientific observations to detect environmental change. A discussion on Arctic terrestrial ecosystems, Ambio 13, pp. 18-23.

IPCC, 2014a Climate Change 2014. Synthesis Report. Contribution of Working Groups I, II and III to the Fifth Assessment Report of the Intergovernmental Panel on Climate Change [Core Writing Team, R. K. Pachauri \& L. A. Meyer (eds)] (Geneva, IPCC).

$2014 \mathrm{~b}$ Climate Change 2014. Impacts, Adaptation, and Vulnerability. Part A: Global and Sectoral Aspects and Part B: Regional Aspects. Contribution of Working Group II to the Fifth Assessment Report of the Intergovernmental Panel on Climate Change [C. B. Field, V. R. Barros, D. J. Dokken, K. J. Mach, M. D. Mastrandrea, T. E. Bilir, M. Chatterjee, K. L. Ebi, Y. O. Estrada, R. C. Genova, B. Girma, E. S. Kissel, A. N. Levy, S. MacCracken, P. R. Mastrandrea \& L. L. White (eds)] (United Kingdom and New York, Cambridge University Press).

2014c Climate Change 2014. Mitigation of Climate Change. Contribution of Working Group III to the Fifth Assessment Report of the Intergovernmental Panel on Climate Change [O. Edenhofer, R. Pichs-Madruga, Y. Sokona, E. Farahani, S. Kadner, K. Seyboth, A. Adler, I. Baum, S. Brunner, P. Eickemeier, B. Kriemann, J. Savolainen, S. Schlömer, C. von Stechow, T. Zwickel \& J. C. Minx (eds)] (United Kingdom and New York, Cambridge University Press).

Krupnik, I., C. Aporta, S. Gearheard, G. J. Laidler \& L. Kielsen Holm (eds) 2010 SIKU: Knowing Our Ice. Documenting Inuit Sea Ice Knowledge and Use (Berlin, Springer).

Latour, B. [1991] 1993 We have Never Been Modern (Cambridge, Massachusetts, Harvard University Press).

Lavrillier, A. 2005 Nomadisme et adaptations sédentaires chez les Évenks de Sibérie postsoviétique: 'jouer' pour vivre avec et sans chamanes, $\mathrm{PhD}$ thesis (Paris, Ecole Pratique des Hautes Etudes, Section des sciences religieuses), $2 \mathrm{t}$.

2005-2006 S'orienter avec les rivières chez les Évenks du Sud-Est sibérien. Un système d'orientation 
spatial, identitaire et rituel, Études mongoles, sibériennes, centrasiatiques et tibétaines 36-37, pp. 95-138.

2008 Comment les Évenks de Sibérie méridionale ont modifié le rituel sur le gibier tué, Annales de la Fondation Fyssen 22, pp. 112-121.

2011a Creation and persistence of cultural landscape among the Siberian Evenkis: two conceptions of "sacred" space, in P. Jordan (ed.), Landscape and Culture in Northern Eurasia (Walnut Creek, Left Coast Press Inc.), pp. 215-231.

2011 b Renne domestique, renne sauvage face au réchauffement, in M. Raccurt \& R. Chernokian (eds), Mondes polaires. Hommes et biodiversités des défis pour la sciences (Paris, Publication INEE/ Prospective polaire, édition du Cherche Midi), pp. 142-145.

2013 Climate change among nomadic and settled Tungus of Siberia: continuity and changes in economic and ritual relationships with the natural environment, Polar Record 50, pp. 260-271.

Lavrillier, A. \& S. Gabyshev 2015 Community-based observatory, Evenk: Amur-Yakutia, [online, URL: http://www.arcticbrisk.org/node/67, accessed 28 February 2017].

2016 How Evenki Reindeer Herders in Siberia Conceive Extreme Event? BRidging Indigenous and Scientific Knowledge about Global Change in the Arctic: Adaptation, and Vulnerability of Society \& Environment, Conference, Indigenous Knowledge and Climate Change, COP 22, Marrakesh, 2-3 November. 2017 An Arctic Indigenous Knowledge System of Landscape, Climate and Human Interactions. Evenki Reindeer Herders and Hunters (Fürstenberg, Kulturstiftung Sibirien, Studies in Social and Cultural Anthropology).

Lavrillier, A., S. Gabyshev \& M. Rojo 2016 The sable for Evenki reindeer herders in Southeastern Siberia: interplaying drivers of changes on biodiversity and ecosystem services: climate change, worldwide market econonomy and extractive industries, in M. Roué \& Z. Molnar (eds), Indigenous and Local Knowledge of Biodiversity and Ecosystems Services in Europe and Central Asia: Contributions to an IPBES regional assessment (Paris, UNESCO, Knowledge and Nature 9), pp. 111-128.

Lavrillier, A., M. Rojo, C. Claud, R. Chondan \& S. Gabyshev 2014 Development of two communitybased transdisciplinary observatories in Siberia among the Evenk and the Tuva-Tozhu reindeer herders, Russian Federation, Conference, Climate change assessments and the 'Best available knowledge': The challenge of bridging disciplines and knowledge systems, UNESCO, Paris, 3 November.

Lenclud, G. 1996 Le grand partage ou la tentation ethnologique, in G. Althabe, D. Fabre \& G. Lenclud (dirs) Vers une ethnologie du présent, Ethnologie de la France 7, pp. 9-37.

Merriam-Webster 2018, "Scientific method", in Merriam-Webster Dictionary [online, URL: https:// www.merriam-webster.com/dictionary/scientific\%20methods, accessed 3 May 2018]

Morss, R. E., O. V. Wilhelmi, G. A. Meehl \& L. Dilling 2011 Improving societal outcomes of extreme weather in a changing climate. An integrated perspective, Annual Review of Environment and Resources 36(1-25), pp. 1-27. [online, URL: www.annualreviews.org, by University of Oxford/ Bodleian Library, accessed 1 November 2012].

Nadasdy, P. 1999 The politics of TEK. Power and the 'integration' of knowledge, Arctic Anthropology 36, pp. 1-18.

Nader, L. (ed.) 1996 Naked Science. Anthropological Inquiry into Boundaries, Power and Knowledge (New York, London, Routledge).

Nakashima, D. J., K. Galloway McLean, H. D. Thulstrup, A. Ramos Castillo \& J. T. Rubis 2012. Weathering Uncertainty. Traditional Knowledge for Climate Change Assessment and Adaptation (Paris/ Darwin, United Nations Educational, Scientific and Cultural Organization and United Nations University). 
Nuttall, M. 2009 Living in a world of movement: human resilience to environment instability in Greenland, in S. A. Crate \& M. Nuttall (eds), Anthropology and Climate Change. From Encounters to Actions (Walnut Creek, Left Coast Press), pp. 292-310.

Obeyesekere, G. 1992 The Apotheosis of Captain Cook. European Mythmaking in the Pacific, (Princeton, Princeton University Press).

Oskal, A., J. M. Turi, S. D. Mathiesen \& P. Burgess (eds) 2009 EALAT Reindeer Herder's Voice. Reindeer Herding, Traditional Knowledge and Adaptation to Climate Change and Loss of Grazing Land (Kautokeino/ Guovdageadnu: International Centre for Reindeer Husbandry) [online, URL: http:// reindeerherding.org/wp-content/uploads/2013/06/EALAT-Final-Report.pdf, accessed 25 February 2017]

Retter, G.-B. 2015 The position of indigenous knowledge on the roadmap for future Arctic research, in ISAR-4 - ICARP III Plenary Keynote Speech 29, April, Arctic Science Summit Week 2015, pp. 1-11. [online, URL: http://www.arcticpeoples.org/images/ ASSW15_Keynote_29.04.15_GBR.pdf, accessed 2 March 2017]

Said, E. [1978] 2006 Orientalism (New York, Penguin Books).

Therrien, M. 2007 Les Inuits ne trouvent pas ça extrême, Université de tous les savoirs, conférences de l'année 2007 [online, URL: https://www.canal-u.tv/video/ universite_de_tous_les_savoirs/les_inuits_ne_trouvent_pas_ca_extreme_michele_therrien.1518, accessed 17 September 2018]

UNFCCC, 2015 Paris Agreement [online, URL: https://unfccc.int/files/essential_background/ convention/application/pdf/english_paris_agreement.pdf, accessed 3 March 2016]

Vasilevich, G. M. 1958 Èvenkiisko-russkii slovar' [Evenki-Russian dictionary] (Moscow, Gosudarstvennoe izdatel'stvo inostrannyh i natsionnyh slovarei).

\section{NOTES}

1. The word comes from the Latin scientia, meaning "knowledge", itself from scire - "to know". Science has been defined thus: "the systematic study of the nature and behaviour of the material and physical universe, based on observation, experiment, and measurement, and the formulation of laws to describe these facts in general terms", or "any body of knowledge organized in a systematic manner" (Collins 2016).

2. The Evenki emic scientific approach is similar to the Western definition of "the scientific method": "principles and procedures for the systematic pursuit of knowledge involving the recognition and formulation of a problem, the collection of data through observation and experiment, and the formulation and testing of hypotheses" (Merriam-Webster dictionary 2018). 3. UNEP (United Nations Environmental Program), UNFCCC (United Nations Framework Convention on Climate Change), IPCC (Intergovernmental Panel on Climate Change), IPBES (Intergovernmental Science-Policy Platform on Biodiversity and Ecosystem Services).

4. From observations by the first author during conferences related to these topics.

5. Census of the Russian Federation, see Federal State Statistics Service2010.

6. In several villages of this region, the population mostly speaks Yakut and Russian.

7. The BRISK project (Bridging Indigenous and Scientific Knowledge about Global Changes in the Arctic: Adaptations and Vulnerabilities of Environment and Societies) prepares transdisciplinary studies of global changes (climatic, environmental, socioeconomic, etc.). The BRISK project allows us to make comparisons at several levels: it examines, in different socio-political contexts, humannatural environment relationships by comparing different types of reindeer herding in Eurasia 
and it considers the notion of "extreme meteorological events" from the differing perspectives of climate scientists and indigenous peoples. This project has brought together indigenous peoples, social anthropologists, climatologists, ecologists, geographers, and UNESCO. The authors of the project are: A. Lavrillier, D. Nakashima, M. Roué, and C. Claud. It is funded by the ANR (2013-2016) and the IPEV project BRISK's OBS (ENV) (2014-2018) (www.arcticbrisk.org, http://www.cearc.fr/ content/brisk): it is also partly funded by the French Chantier Arctique project PARCS (Pollution in the Arctic System) and CNRS (INSU). In this paper, the word "Arctic" designates both Arctic (from the $66^{\circ} \mathrm{N}$ ) and Subarctic regions, i.e. according to criteria relating to climate, the permafrost, and the presence of various reindeer herding peoples.

8. These families belong to the following kinship groups: the Kolesovs, the Pavlovs, the Egorovs, the Safronovs, the Iakovlevs, the Gabyshevs, the Vasilevs, the Savins, the Nikolaevs, the Urkanovs, the Andreevs, the Abramovs, the Kurbaltunovs, the Isakovs, the Rostolovs, the Trenkins, the Kirillovs, the Maksimovs, and the Neustroevs.

9. Related positions can be found in projects among the Yakut, where informants are considered "research partners" (Crate 2008, Crate \& Federov 2013), among the Nenets by involving reindeer herder observations in research (Forbes et al. 2009), among the Inuit peoples with pioneering work integrating indigenous TEK from the Siku (Krupnik et al. 2010) or Siku-Inuit-Hila projects (Gearheard et al. 2013), and among the Sami reindeer herders who ordered the research project Ealat (Oskal et al. 2009).

10. E.g. Observatory for Sciences of the Universe of Versailles Saint-Quentin en Yvelines (OVSQ), University of Versailles Saint-Quentin en Yvelines (UVSQ), and the French National Research Agency (ANR).

11. For a developed analysis of our methodologies, the issues we faced, the status of data in the sciences and TEK, and our research results, see Lavrillier \& Gabyshev 2017, pp. 11-59, 451-458.

12. For analysed examples of such theories and modelling, see Lavrillier \& Gabyshev 2017 (in particular pp. 370-458).

13. Similar types of knowledge of snow and sea ice were documented among other Arctic peoples (cf. for instance, Oskal et al. 2009, Krupnik et al. 2010, Gearheard et al. 2013).

14. This citation is a compilation of phrases that were repeatedly uttered in interviews between 2013 and 2018.

15. This part of the paper is a first step in our transdisciplinary discussion (anthropology, bioethnology, indigenous knowledge, climatology) about the notion of an extreme event: it is one of the interdisciplinary links of the BRISK project. Mainly based on the social sciences and TEK, this paper will be followed by one with a climatologic approach that uses the same data.

16. This research was conducted with the choice not to mention the term "climate change". It focused on the global perception of climate change, adaptive practices, the native notion of vulnerability, and potential changes in the perception of a link between the natural environment and human society (Lavrillier 2013).

17. In this paper, the word "anomaly(ies)" will be used in terms of its Evenki meaning, which is defined in the text above.

18. For a detailed analysis of this term, see Lavrillier \& Gabyshev 2017, pp. 452-454.

19. Many herders uttered these two phrases in the interviews we gathered between 2006 and 2014.

20. For more details, see Lavrillier 2011a, Lavrillier et al. 2014.

21. For more details, see Lavrillier et al. 2016, pp. 118-119.

22. This citation is a compilation of phrases that appeared repeatedly in the interviews gathered by the authors during between 2013 and 2018 .

23. For more details, see Lavrillier \& Gabyshev 2016.

24. From discussions of our results about Evenki TEK with specialists on snow and hydrology and with Joel Heath from the SEA-AES project among the Canadian Inuits (see above). 


\section{ABSTRACTS}

This paper was co-written by Lavrillier (anthropologist) and Gabyshev (reindeer herder and coresearcher) on the basis of their field materials, with documentation and analysis of complex traditional environmental knowledge. After discussing the methodology of a community-based transdisciplinary observatory for monitoring the climate and environmental changes with herders, the paper reveals some results from their co-production. It presents the emic science of climate (its typologies and concepts) the Evenki use for understanding norms and anomalies, observing and predicting changes, and adaptation. The authors then develop the notion of an "extreme process" and show that it is more suitable than the concept of an "extreme event" (used in climate change studies) for defining how the Evenki face climate change. By analysing several case studies, they define this notion as the interaction between an accumulation of climatic anomalies in different domains and other environmental disruptions. When external factors (economical, political, or industrial) join the mix, it results in a "hybrid extreme process", which seriously questions the resilience of this nomadic society.

Cet article, co-écrit par Lavrillier (anthropologue) et Gabyshev (éleveur de rennes et cochercheur) se base sur leur matériaux de terrain qui documentent et analysent le système complexe de savoirs écologiques. Ayant discuté leur méthodologie d'observatoire transdisciplinaire installé chez une communauté évenk pour le monitoring, avec les éleveurs, des changements climatiques et environnementaux, l'article dévoile certains résultats de cette coproduction des savoirs. L'article présente la science émique du climat (ses typologies et concepts) que les Évenks utilisent pour comprendre normes et anomalies, pour observer et prédire les changements et pour s'adapter. Les auteurs développent la notion de "processus extrême " comme étant plus représentative de la manière dont les nomades font face au changement climatique, que "évènement extrême » (utilisée usuellement). Analysant plusieurs cas d'études, ils définissent cette notion comme une accumulation d'anomalies climatiques de différentes origines, et parfois d'autres dysfonctionnements de l'environnement. Quand des facteurs extérieurs (économiques, politiques, industriels) s'ajoutent, cela devient un " processus extrême hybride », qui, lui, questionne sérieusement la résilience de cette société nomade.

\section{INDEX}

Keywords: community-based observatory, cognition, transdisciplinarity, reindeer herding, hunter, traditional ecological knowledge, climate change, environmental change, predators Mots-clés: observatoire basé chez les communautés, transdisciplinarité, élevage du renne, chasse, savoir écologique traditionnel, changements climatiques, changements environnementaux, système cognitif, prédateur

\section{AUTHORS}

\section{ALEXANDRA LAVRILLIER}

Alexandra Lavrillier is Associate Professor in Social and Cultural Anthropology at the CEARC (Cultures, Environments, Arctic, Representations, Climate) of University of Paris-Saclay (UVSQ). Fluent in Evenki, she performed around 9 years of fieldwork. Her research interests cover comparative studies of nomadism, hunting, reindeer herding, landscape management, 
representations of the natural environment, shamanism, lifestyles and adaptations brought by postsocialism, the market economy and climate change among Evenki, Even and Yakut. She has published on ritual, the uses of space and landscape, childhood, ethnolinguistics, ecological knowledge system and environmental changes. She led scientific projects like BRISK, PARCS, POLARIS.

alavrillier@gmail.com

\section{SEMEN GABYSHEV}

Semen Gabyshev is a Evenki reindeer herder and hunter with 28 years of experience in the Amur region and Yakutia (Russia). A native bearer of the Evenki TEK and language, since 2012-2013 he has been an associate member of CEARC and an indigenous co-researcher in scientific projects (BRISK, POLARIS, PARCS, MI CNRS “Changements en Sibérie”, BRISK's OBS ENV). He is the coauthor of scientific book and papers.

Bulchut.metakar@yandex.com 